\title{
Adair-Steadman (41FS2) - Survey at a Folsom Site in the Brazos River drainage on the Southern Plains
}

Stance Hurst

Eileen Johnson

Follow this and additional works at: https://scholarworks.sfasu.edu/ita

Part of the American Material Culture Commons, Archaeological Anthropology Commons, Environmental Studies Commons, Other American Studies Commons, Other Arts and Humanities Commons, Other History of Art, Architecture, and Archaeology Commons, and the United States History Commons

Tell us how this article helped you.

This Article is brought to you for free and open access by the Center for Regional Heritage Research at SFA ScholarWorks. It has been accepted for inclusion in Index of Texas Archaeology: Open Access Gray Literature from the Lone Star State by an authorized editor of SFA ScholarWorks. For more information, please contact cdsscholarworks@sfasu.edu. 
Adair-Steadman (41FS2) - Survey at a Folsom Site in the Brazos River drainage on the Southern Plains

\section{Creative Commons License}

\section{(c) (1) \&}

This work is licensed under a Creative Commons Attribution-NonCommercial 4.0 International License 


\title{
ADAIR-STEADMAN (41FS2) - SURVEY AT A FOLSOM SITE IN THE BRAZOS RIVER DRAINAGE ON THE SOUTHERN PLAINS
}

\author{
The 2015 through 2019 Work
}

\section{Stance Hurst and Eileen Johnson}

\author{
Lubbock Lake Landmark Quaternary Research Center Series \\ Number 26 \\ 2019 \\ Museum of Texas Tech University
}

Texas Historical Commission

Permit for Archeological Investigations \#7137

Dr. Stance Hurst, Principle Investigator 



\section{Table of Contents}

Table of Contents

Illustrations

Tables

Abstract

Introduction

Physiographic Setting

Theoretical Perspective

Methodology

Field Methodology

6

Analytical Methodology

Results

2015 Field Season

2016 Field Season

12

2017 Field Season

15

2018 Field Season $\quad 17$

2019 Field Season $\quad 20$

$\begin{array}{ll}\text { Spatial Analysis } & 21\end{array}$

Optical Stimulated Luminescence (OSL) dating 22

$\begin{array}{ll}\text { Discussion } & 28\end{array}$

Concluding Remarks $\quad 29$

$\begin{array}{ll}\text { Appendix A } & 31\end{array}$

$\begin{array}{ll}\text { References } & 35\end{array}$ 


\section{ILLUSTRATIONS}

Page Number

Figure 1. Location of Adair-Steadman (41FS2) on the Rolling Plains of Texas.

Figure 2. Location of Adair-Steadman (41FS2) in relation to the Quarry site (41JS12) and the Clear Fork of the Brazos River.

Figure 3. Location of piece-point-plotted lithic artifacts recovered during the 2015 pedestrian survey at Adair-Steadman (41FS2).

Figure 4. Uniface TTU-A7-50087 located during the 2015 pedestrian survey at Adair-Steadman (41FS2).

Figure 5. Uniface TTU-A7-50100 located during the 2015 pedestrian survey at Adair-Steadman (41FS2).

Figure 6. Location of piece-point-plotted lithic artifacts recovered during the 2016 pedestrian survey at Adair-Steadman (41FS2).

Figure 7. Biface TTU-A7-67791 located during the 2016 pedestrian survey at Adair-Steadman (41FS2).

Figure 8. Location of piece-point-plotted lithic artifacts recovered during the 2017 pedestrian survey at Adair-Steadman (41FS2).

Figure 9. A dense cloud model of the Adair-Steadman (41FS2) site.

Figure 10. A digital elevation model of the Adair-Steadman (41FS2) site.

Figure 11. An orthomosiac model of the Adair-Steadman (41FS2) site.

Figure 12. Location of piece-point-plotted lithic artifacts recovered during the 2018 pedestrian survey at Adair-Steadman (41FS2).

Figure 13. Lithic cluster analysis of objects found during the 1999-2014 and 2015-2019 pedestrian survey at Adair-Steadman (41FS2). 


\section{ILLUSTRATIONS}

\section{Page Number}

Figure 14. Profile drawing of OSL sampling areas - west wall excavation unit 23 $36 \mathrm{~N} 21 \mathrm{~W}$ at Adair-Steadman (41FS2).

Figure 15. Dr. Vance Holiday removing OSL samples — west wall excavation unit 36N21W at Adair-Steadman (41FS2).

Figure 16. Radial graph of single-grain DEs of OSL sample UW3016 — west wall excavation unit 36N21W at Adair-Steadman (41FS2).

Figure 17. Radial graph of single-grain DEs of OSL sample UW3017 — west wall excavation unit 36N21W at Adair-Steadman (41FS2).

Figure 18. Radial graph of single-grain DEs of OSL sample UW3018 — west wall excavation unit $36 \mathrm{~N} 21 \mathrm{~W}$ at Adair-Steadman (41FS2).

Figure 19. Radial graph of single-grain DEs of OSL sample UW3019 - west wall excavation unit 36N21W at Adair-Steadman (41FS2).

Figure 20. Location of OSL samples and ages - west wall excavation unit $36 \mathrm{~N} 21 \mathrm{~W}$ at Adair-Steadman (41FS2).

Figure 21. View from the east of Adair-Steadman vegetation: a) taken in May 2016 indicating some weedy growth within primarily a grassland setting (note the thick mesquite growth in the distance off of the site); b) taken in September 2017 indicating increase in weedy growth and sprouting of mesquite trees c) taken in May 2018 indicating increased growth and number of young mesquite trees.

Figure 22. Applying herbicide on one of the mesquite trees at Adair-Steadman that had sprouted in 2016 to 2017. 


\section{TABLES}

Page Number

Table 1. Summary data for the 2015 through 2019 field season at

8 Adair-Steadman (41FS2).

Table 2. Flakes recovered from the 2015 pedestrian survey at Adair-Steadman (41FS2).

Table 3. Debris recovered from the 2015 pedestrian survey at Adair-Steadman. (41FS2).

Table 4. Unifaces recovered from the 2015 pedestrian survey at Adair-Steadman (41FS2).

Table 5. Flakes recovered from the 2016 pedestrian survey at Adair-Steadman (41FS2).

Table 6. Debris recovered from the 2015 pedestrian survey at Adair-Steadman (41FS2).

Table 7. Biface recovered from the 2016 pedestrian survey at Adair-Steadman (41FS2).

Table 8. Flakes recovered from the 2017 pedestrian survey at Adair-Steadman (41FS2).

Table 9. Debris recovered from the 2017 pedestrian survey at Adair-Steadman (41FS2).

Table 10. Flakes recovered from the 2018 pedestrian survey at Adair-Steadman (41FS2).

Table 11. Debris recovered from the 2017 pedestrian survey at Adair-Steadman (41FS2).

Table 12. Optical Stimulated Luminescence results from the Adair-Steadman (41FS2) site. 


\begin{abstract}
Excavations led by Texas State Archeologist Curtis Tunnell from 1969-1974 identified Adair-Steadman (41FS2) as a Folsom period tool production workshop primarily aimed at producing Folsom points. The Lubbock Lake Landmark's regional research program continued the exploration of Adair-Steadman through five annual 1-day surveys from 2015-2019. An Unmanned Aerial Vehicle (UAV) drone was flown to document the site's surface using photogrammetry. Dating sediment samples collected in 2013 , using the Optical Stimulated Luminescence (OSL) technique, was completed in 2016. Blossoming mesquite trees were treated with alcohol-based herbicides to maintain the natural landscape at Adair-Steadman in the absence of fire.

Results from pedestrian survey indicates that the exposure of new lithic objects from erosion has slowed down over the last five years. A new lithic cluster area was identified that could be an indicator of an activity area with a subsurface component. A 3D dense cloud, a high resolution digital elevation model, and a high resolution orthomosiac map was created from the overlapping images captured by the UAV. This information was useful in documenting the current surface at Adair-Steadman and monitoring changes in the future. Results from OSL dating indicated that the clay band (a lamellae layer) identified and sampled in 2013 may provide a reliable stratigraphic marker. The sediments above the lamellae layer were late Holocene in age. In contrast, the sediments below the lamellae layer dated to the middle Holocene.
\end{abstract}




\section{INTRODUCTION}

The Adair-Steadman (41FS2) site, on the Southern Plains, is situated on a high terrace north of the Clear Fork of the Brazos River in Fisher County, Texas (Figures $1,2)$. The site lies within the margin of an extensive dune field containing active and stabilized dunes. Aeolian dune sands apparently buries the sites shortly after it was abandoned (Holliday, 1997:161).

As part of the continuing investigation into hunter-gatherer use of the AdairSteadman site, fieldwork for the past five years (2015-2019) consisted of annual 1-day pedestrian surveys to map and collect newly exposed artifacts. An unmanned aerial vehicle (UAV) drone was flown over the site (2017) to create a detailed 3D model for future research and monitoring. Luminescence dating of sediment samples collected in 2013 was completed in 2016 (Hurst and Johnson, 2016a). Results of this work provided important clues to the impact of bioturbation at Adair-Steadman.

\section{PHYSIOGRAPHIC SETTING}

Adair-Steadman is situated on the Rolling Plains of Texas that is characterized by low topographic relief. The Brazos River is the largest drainage in the region and extends from the Llano Estacado to the northwest to the Gulf of Mexico in the south. Prior to historic farming, the area is characterized by short or mixed grass prairies with cottonwood and willow along streams and riverbanks. Drought resistant species of brush and scrubby woodland would have been found in the upland areas, away from water sources (Shelford, 1963).

Grey wolf and black bear once were common but were extirpated from the area, as was black-footed ferret. The carnivore guild also contained coyote, gray fox, mountain lion, bobcat, ringtail, raccoon, badger, and skunk. Bison, pronghorn, and deer were the most common large game herbivores (Schmidly, 2004; Jones et al., 1985). In addition to mammals, numerous species of lizard, reptile, and bird also could be found. The climate today is strongly continental, meaning it has large temperature ranges 
that are not influenced by large bodies of water. Currently, the region receives $\sim 61 \mathrm{~cm}$ of rainfall annually, most of which falls in the spring through autumn (Bomar, 1995). Summer rains occur primarily in the form of severe thunderstorms that arise as a result of daytime heating and the absence of high pressure. Summer droughts, however, also occur due to high pressure that can dominate the region (Barry, 1983; Haragan, 1983:67). Precipitation in the form of winter snowfall is minimal. Conditions are much wetter during the late Pleistocene with an increase in sea, river, and lake levels (Baker, 1983; Friedman, 1983; Smith and Street-Perrott, 1983). This rise is due to an increase in effective precipitation and a reduction in the rate of evaporation presumably due to climatic changes.

Figure 1. Location of Adair-Steadman (41FS2) on the Rolling Plains of Texas. 
Figure 2. Location of Adair-Steadman (41FS2) in relation to the Quarry site (41JS12) and the Clear Fork of the Brazos River. 
By the end of the Pleistocene, a drying trend was underway. Conditions still were much moister than those in the region today. Water levels, however, were beginning to drop and lakes were becoming seasonal (Smith and Street-Perrott, 1983; Reeves, 1973). Between 12,000 and 11,000 radiocarbon yrs BP, an equitable, humid, maritimelike paleoclimate existed that lacked season extremes, with a lower mean annual temperature than today, cooler summers, and warmer winters that lacked extended freezing conditions (Johnson, 1991). A winter rainfall pattern was coupled with cool dry summers. Savannas or scrub grasslands existed throughout the Southern Plains (Bryant, 1977; Lundelius et al., 1983).

The time of 11,000 radiocarbon yrs BP marks the biotic and ecosystemic end of the Pleistocene conditions on the Southern Plains (Baker, 1983; Lundelius et al., 1983; Johnson, 1986, 1987, 2017; Ferring, 2001). Available moisture and humidity levels continue to decrease, reflecting the intensification of the warming and drying trend and more marked seasonality. Mild winters persist with occasional periods of freezing conditions. Yearly precipitation is decreasing although enhanced winter rains appeared to have continued. Native trees form a component of the vegetation community, generally restricted to wooded waterways. The grassland is a mixed prairie, albeit with a different composition than today's mixed prairie (Humphrey and Ferring, 1994; Nordt et al., 1994; Holliday, 1995; Holliday et al., 2008; Fredlund et al., 2003; Johnson, 2007). Ancient bison emerges in the early Holocene fauna as the major grazing herd herbivore, with deer and pronghorn continuing as large browsers.

\section{THEORETICAL PERSPECTIVE}

The Lubbock Lake Landmark regional research approach is focused on people-land relationships (Johnson, 1987, 1991, 2002). The evolutionary ecology view of culture is through explanatory mechanisms of rational choice and natural selection as causal factors (Smith and Winterhalder, 1993:39; Winterhalder and Smith, 1992:21). Cultural 
changes have their basis in the actions of individuals within ecologically situated choices (Smith and Winterhalder, 1992:39; Winterhalder and Goland, 1997:126). Primary condition factors for determining adaptations, then, are the nature and distribution of resources (Kaplan and Hill, 1992:167). The underlying goal of the research is to understand the dynamics of the interface of culture, landscape, and climate reflected in adaptive responses.

Within the broader regional research program, cultural continuity and change within hunter-gatherer economic systems are being examined in relationship to changing ecosystems. The major hunter-gatherer subsystems reflected in the archaeological record are subsistence and technology. The basic cultural assumption is that inferences concerning hunter-gatherer technology and subsistence can be made from analysis of the lithic, faunal, and floral materials.

The approach to people-land relationships is in the context of a technologicalenvironmental explanation given the concept that culture is a people's adaptation to the environment. The interaction, therefore, between culture and environment is facilitated by technology (Bettinger, 1980; Hayden, 1981). A landscape approach is used in examining the interaction between people and their environments and land use patterns as people generally are involved actively in a dynamic relationship with the landscape. This perspective is a mechanism to determine the way people perceive, interact with, and transform the environment (Savage, 1990). A landscape approach provides a framework in which to assess land use and regional patterns and examine resource exploitation (Rossignol and Wandsnider, 1992).

The continued exploration into the record of cultural occupations on the Southern Plains had at least one goal and several objectives.

GOAL 1: to understand the dynamics of the interface of culture and climate reflected in adaptive responses and climatic change detected in the archaeological record. 
objective 1: to delineate the lifeways of the aboriginal hunter-gatherer peoples through landscape utilization and household maintenance tasks.

objective 2: to examine subsistence strategies through optimal foraging theory, risk management, and nutritional parameters by inferred behavioral patterns revealed in excavated materials using precise recovery techniques, mapping, and documentation.

objective 3: to analyze site type, landscape and resource utilization, movement patterns, and timing of activities to provide information on the structural organization of hunter-gatherers.

\section{METHODOLOGY}

\section{Field Methodology}

The areal extent of investigation at Adair-Steadman covered 2.92ha (7.22ac). The fieldwork consisted of $100 \%$ pedestrian survey. Lubbock Lake Landmark methodology (Johnson, 1987) was followed.

Pedestrian survey was completed by crew members walking $\sim 2 \mathrm{~m}$ linear transects across the entire site. Artifacts were flagged, their provenience recorded using a Trimble R8 GPS base station. The GPS data points contained sub-centimeter accuracy. A UAV was used to document the Adair-Steadman landscape. A DJI Inspire 1 UAV carrying a high resolution 16 megapixel Zenmuse $\mathrm{X} 5$ camera was flown over the site at $\sim 30 \mathrm{~m}$. Images were captured across the entire site with a $70-80 \%$ overlap at an oblique angle. Agisoft Metashape software was used to convert the images into a 3D dense cloud model. The software also was used to create a digital elevational model and georeferenced orthomosiac image of the site's surface to delineate topographic features. 


\section{Analytical Methodology}

Lithic material was sorted into two categories, either tool or debitage, and a basic analysis was completed. Tools were measured (length, width, and thickness) and material type and source were recorded. Diagnostic tools were identified and placed within the regional cultural typology. Non-diagnostic tools were categorized as uniface, biface, or core.

Debitage was divided further into flakes (debitage with intact platforms) and debris (debitage without intact platforms) (Crabtree, 1972; Cotterell and Kamminga, 1979; Sullivan and Rozen, 1985; Andrefksy, 1998). Regardless of the completeness of the flake, measurements of maximum length, width, and thickness were taken for all identified flakes. Platform maximum length and width measurements were obtained using digital calipers (Mitutoyo Corp. 0.01-150mm).

A basic nominal flake platform (adapted from Andrefksy, 1998) was followed. Platform type was assigned to one of five categories, these being flat, complex, abraded, cortical, or crushed. A flat platform was defined as a clear bulb of percussion being present with no evidence of platform preparation. A complex platform was defined as a clear bulb of percussion being present and flaked retouch associated with platform preparation. An abraded platform was defined as a clear bulb of percussion being present and a worn and roughened surface associated with platform preparation. A cortical platform was defined as a bulb of percussion being present and characteristics consistent with the outer cortical surface of the material type. A crushed platform was defined as a shattered bulb of percussion so that the platform no longer was recognizable.

Material type and source designation was based on macroscopic and microscopic inspection of individual pieces and assigned as resulting from one of several lithic source areas (Banks, 1990). Chert was the primary material type. Material not recognized to a source was assigned as "source unknown." Additionally, Edwards 
Formation and Edwards-like material was subjected to ultraviolet florescence at both short and long waves to aid in determination (Banks, 1990; Hillsman, 1992; Hofman et al., 1991).

The spatial distribution of the objects was compared with data from the previous 16 years of Landmark surveys at Adair-Steadman (1999-2014; MacEwen et al., 2006; Hurst and Johnson, 2012, 2016). This analysis was conducted to determine if intact activity areas were present at Adair-Steadman, and if a shift in erosional patterns had occurred in exposing lithic material at different parts of the site. The software Crimestat III was used for establishing clusters based on the Nearest Neighbor Hierarchial Spatial Cluster analysis. Clusters then were mapped within Quantum GIS. A cluster was defined arbitrarily as 10 or more lithics within a $5 \mathrm{~m}$ area.

\section{RESULTS}

The 2015 through 2019 work consisted of an annual 1-day surface survey (Table 1). A total of five field workdays, therefore, was completed. The purpose of the field work was to map and recover any additional artifacts exposed over the year from erosion in order to investigate further the spatial distribution of artifacts.

Table 1. Summary data for the 2015 through 2019 field season at Adair-Steadman (41FS2).

\begin{tabular}{|l|c|c|c|c|c|}
\hline Field Season & $\begin{array}{c}\text { Total Number } \\
\text { of Days } \\
\text { Worked }\end{array}$ & Crew Size & $\begin{array}{c}\text { Accession } \\
\text { Numbers }\end{array}$ & $\begin{array}{c}\text { Range of Catalog } \\
\text { Numbers } \\
\text { (TTU-A7-) }\end{array}$ & Count \\
\hline 2015 & 1 & 3 & TTU2015-035 & $50082-50105$ & 24 \\
\hline 2016 & 1 & 4 & TTU2016-043 & $67788-67796$ & 10 \\
\hline 2017 & 1 & 3 & TTU2017-015 & $68697-68703$ & 7 \\
\hline 2018 & 1 & 4 & TTU2018-022 & $69451-69456$ & 5 \\
\hline 2019 & 1 & 2 & TTU2019-023 & None & 0 \\
\hline Total & $\mathbf{5}$ & & & & $\mathbf{4 6}$ \\
\hline
\end{tabular}

2015 Field Season

A crew of three people completed a $100 \%$ pedestrian survey during the 1-day 2015 season. Two unifacial tools and 22 pieces of lithic debitage were mapped and collected throughout the Adair-Steadman site area (Figure 3; Tables 2-4). All 24 (100\%) of the lithics collected were chert that was sourced to the Edwards Formation. 
The debitage consisted of 15 flakes and seven pieces of debris. Most of the flake platforms were abraded $(n=8 ; 53 \%)$, followed by flat $(n=6 ; 40 \%)$, and crushed $(n=1$; $7 \%$ ). The presence of both abraded and flat platforms indicated that these flaked were detached from both bifacial and blocky core types (e.g., Andrefsky, 1998).

Both unifaces are broken and consisted of only a segment of the tool. Uniface TTU-A7-50087 (Figure 4, Table 4) is a graver tip segment from a flake tool. Microflaking is present on the dorsal surface of the graver tip. Fine flaking often is present on flake grave tools present within Folsom assemblages (Osborn, 2014).

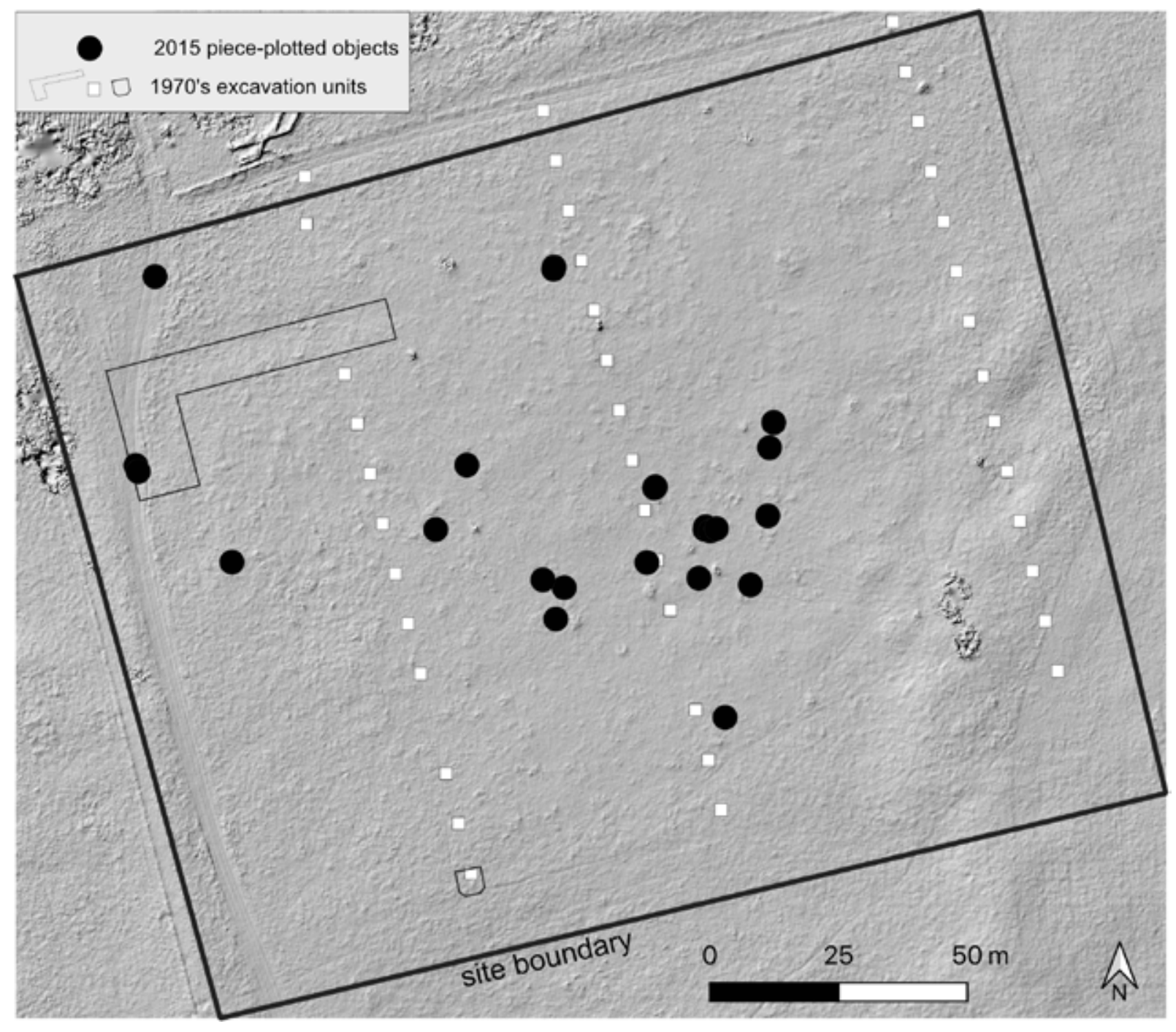

Figure 3. Location of piece-point-plotted lithic artifacts recovered during the 2015 pedestrian survey at Adair-Steadman (41FS2). 
Table 2. Flakes recovered from the $\mathbf{2 0 1 5}$ pedestrian survey at Adair-Steadman (41FS2).

\begin{tabular}{|c|c|c|c|c|c|c|}
\hline $\begin{array}{c}\text { Catalog } \\
\text { Number } \\
\text { (TTU-A7-) }\end{array}$ & Material & Source & Dimensions $\left.\mathbf{( m m}^{*}\right)$ & $\begin{array}{c}\text { Platform } \\
\text { Type }\end{array}$ & $\begin{array}{c}\text { Platform } \\
\text { Dimensions } \\
\left(\mathbf{m m}^{*}\right)\end{array}$ & Count \\
\hline 50093 & chert & Edwards Formation & $32.76,29.28,4.34$ & abraded & $4.57,1.25$ & 1 \\
\hline 50092 & chert & Edwards Formation & $12.26,16.76,2.09$ & abraded & $7.42,2.71$ & 1 \\
\hline 50082 & chert & Edwards Formation & $20.86,23.53,2.87$ & abraded & $5.62,2.22$ & 1 \\
\hline 50099 & chert & Edwards Formation & $21.53,18.15,2.18$ & abraded & $5.42,1.85$ & 1 \\
\hline 50104 & chert & Edwards Formation & $14.83,14.4,1.73$ & abraded & $3.41,1.68$ & 1 \\
\hline 50086 & chert & Edwards Formation & $12.52,17.43,6.18$ & abraded & $16.97,6.18$ & 1 \\
\hline 50102 & chert & Edwards Formation & $40.41,31.11,3.76$ & abraded & $6.14,2.29$ & 1 \\
\hline 50095 & chert & Edwards Formation & $9.21,8.36,0.99$ & flat & $2.45,0.61$ & 1 \\
\hline 50098 & chert & Edwards Formation & $27.34,12.76,2.48$ & flat & $7.05,1.3$ & 1 \\
\hline 50083 & chert & Edwards Formation & $25,17.43,2.88$ & flat & $2.47,1.20$ & 1 \\
\hline 50090 & chert & Edwards Formation & $22.02,16.04,8.07$ & flat & $14.15,8.07$ & 1 \\
\hline 50103 & chert & Edwards Formation & $18.13,32.85,3.15$ & flat & $23.68,2.5$ & 1 \\
\hline 50088 & chert & Edwards Formation & $16.57,22.38,2.31$ & crushed & $\mathrm{n} / \mathrm{a}$ & 1 \\
\hline 50094 & chert & Edwards Formation & $10.47,10.92,2.41$ & abraded & $8.04,2.77$ & 1 \\
\hline 50091 & chert & Edwards Formation & $15.94,10.47,2.18$ & flat & $3.38,1.43$ & 1 \\
\hline Total & & & & & & 15 \\
\hline
\end{tabular}

*length, width, thickness

Table 3. Debris recovered from the 2015 pedestrian survey at Adair-Steadman (41FS2).

\begin{tabular}{|c|c|c|c|c|}
\hline $\begin{array}{c}\text { Catalog Number } \\
\text { (TTU-A7-) }\end{array}$ & Material & Source & $\begin{array}{c}\text { Dimensions } \\
\left(\mathbf{m m}^{*}\right)\end{array}$ & Count \\
\hline 50084 & chert & Edwards Formation & $17.59,16.71,2.04$ & 1 \\
\hline 50096 & chert & Edwards Formation & $18.32,24.38,3.5$ & 1 \\
\hline 50085 & chert & Edwards Formation & $11.44,20.95,3.71$ & 1 \\
\hline 50089 & chert & Edwards Formation & $9.7,13.97,2.13$ & 1 \\
\hline 50097 & chert & Edwards Formation & $12.22,14.58,1.94$ & 1 \\
\hline 50105 & chert & Edwards Formation & $11.5,17.69,1.73$ & 1 \\
\hline 50101 & chert & Edwards Formation & $13.65,14.02,1.15$ & 1 \\
\hline Total & & & & 7 \\
\hline
\end{tabular}

* length, width, thickness 
Table 4. Unifaces recovered from the 2015 pedestrian survey at Adair-Steadman (41FS2).

\begin{tabular}{|c|c|c|c|c|c|c|}
\hline $\begin{array}{c}\text { Catalog } \\
\text { Number } \\
\text { (TTU-A7-.) }\end{array}$ & Material & Source & $\begin{array}{c}\text { Dimensions } \\
\left(\mathbf{m m}^{*}\right)\end{array}$ & $\begin{array}{c}\text { Platform } \\
\text { Type }\end{array}$ & $\begin{array}{c}\text { Platform } \\
\text { Dimensions } \\
\left(\mathbf{m m}^{*}\right)\end{array}$ & Count \\
\hline 50087 & chert & $\begin{array}{c}\text { Edwards } \\
\text { Formation }\end{array}$ & $\begin{array}{c}17.64,30.72, \\
4.21\end{array}$ & flat & $5.32,1.99$ & 1 \\
\hline 50100 & chert & $\begin{array}{c}\text { Edwards } \\
\text { Formation }\end{array}$ & $\begin{array}{c}24.4,22.28, \\
5.62\end{array}$ & $\mathrm{n} / \mathrm{a}$ & $\mathrm{n} / \mathrm{a}$ & 1 \\
\hline Total & & & & & & $\mathbf{2}$ \\
\hline
\end{tabular}

* length, width, thickness
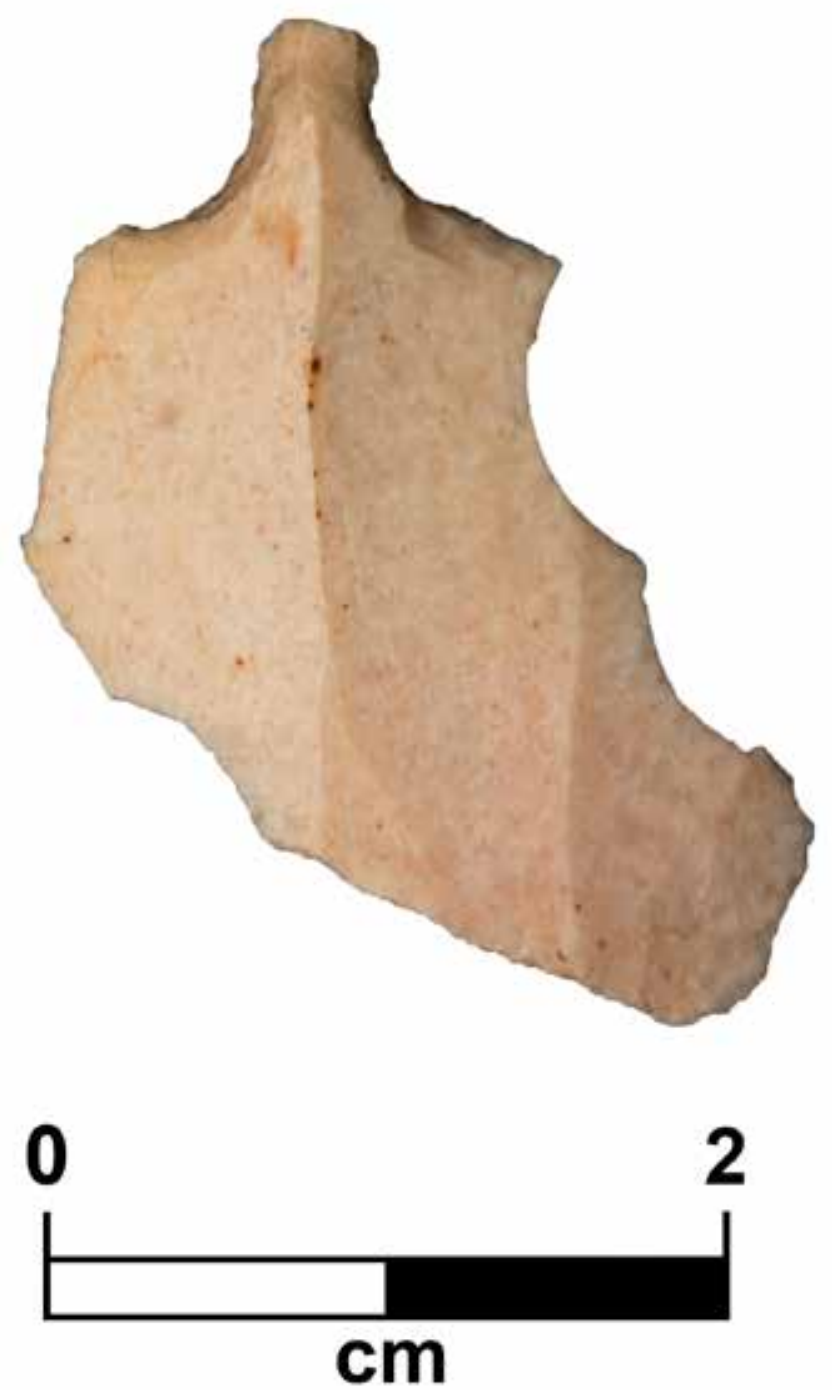

Figure 4. A uniface (TTU-A7-50087) found during the 2015 pedestrian survey at Adair-Steadman (41FS2). 
Uniface TTU-A7-50100 (Figure 5, Table 4) was flaked on the dorsal surface along the right side, the flaking of which formed an edge angle of $69^{\circ}$. Polishing and rounding of the edge suggested the uniface was used as a scraping tool for processing hide or wood (e.g., Odell and Odell-Vereecken, 1980).

2016 Field Season

A crew of four people completed a $100 \%$ pedestrian survey during the 1-day 2016 season. One biface and eight pieces of lithic debitage were mapped and collected throughout the Adair-Steadman site area (Figure 6; Tables 5-7). All nine (100\%) of the lithics collected were chert that was sourced to the Edwards Formation.
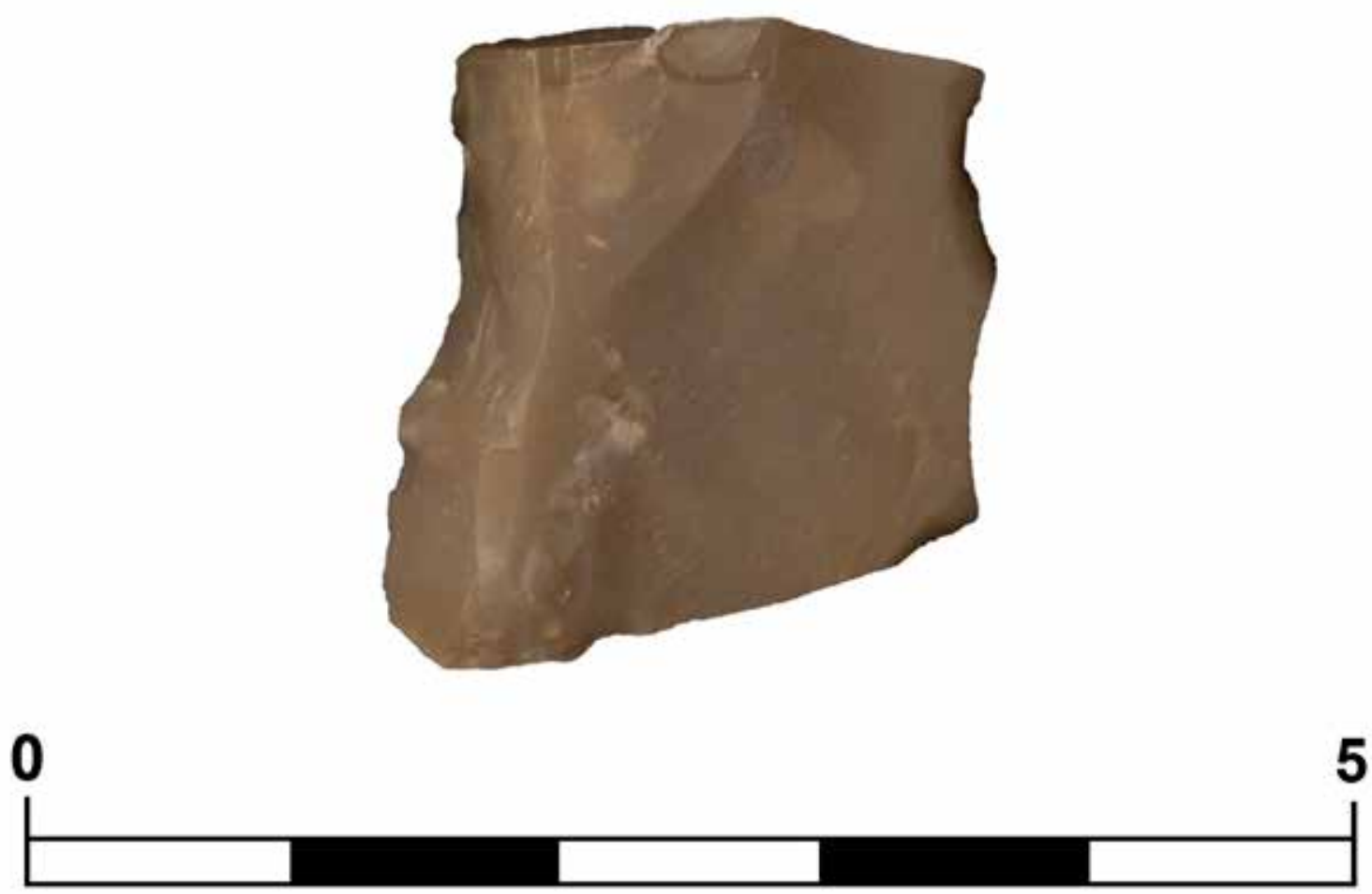

\section{cm}

Figure 5. A uniface (TTU-A7-50100) found during the 2015 pedestrian survey at Adair-Steadman (41FS2).

The debitage consisted of two flakes and six pieces of debris. The flake platforms were classified as flat $(n=1 ; 50 \%)$ and crushed $(n=1 ; 50 \%)$. The presence of a flat platform indicated that this flake was detached from a blocky core (e.g., Andrefsky, 1998). 


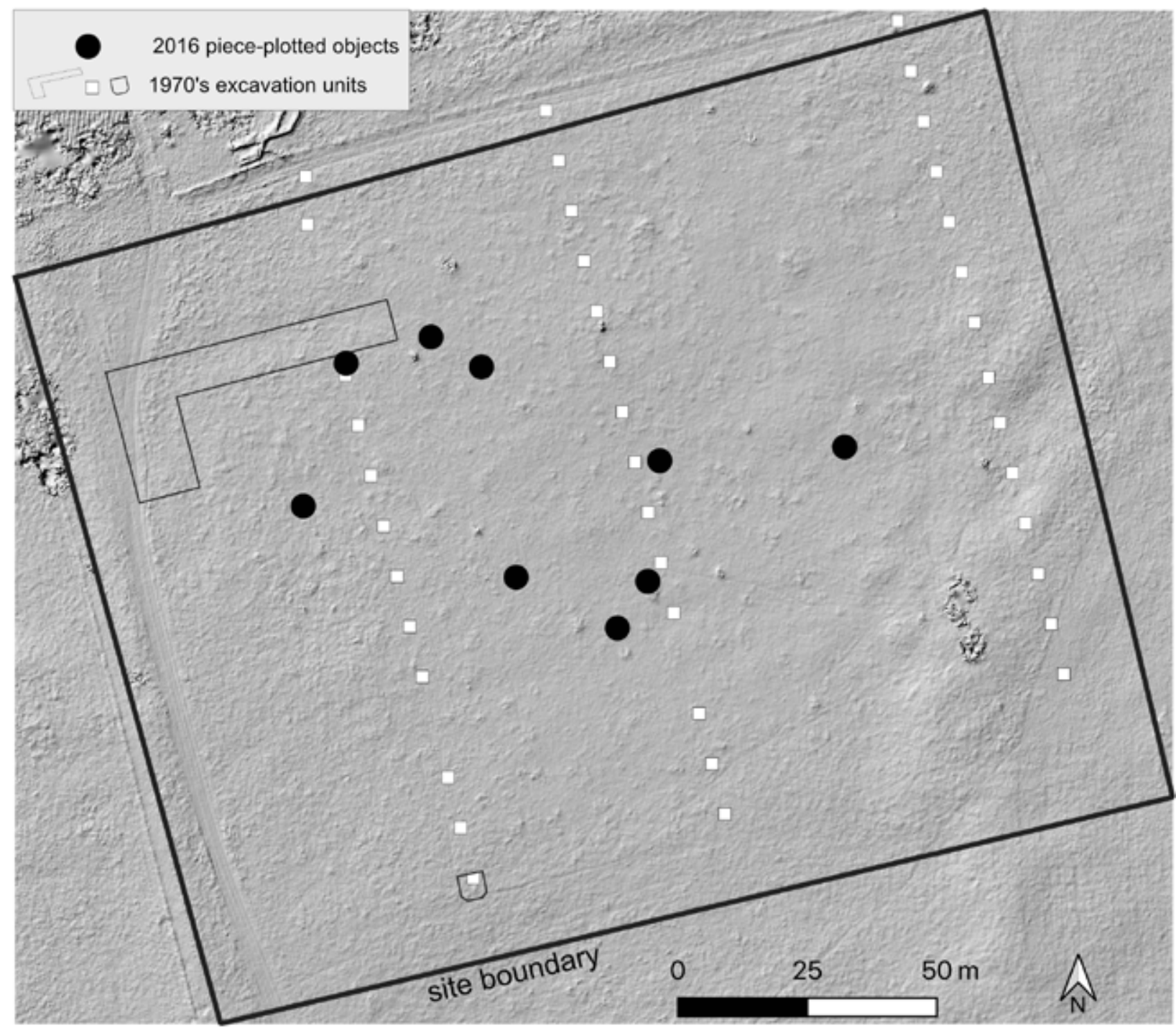

Figure 6. Location of piece-point-plotted lithic artifacts recovered during the 2016 pedestrian survey at Adair-Steadman (41FS2).

Table 5. Flakes recovered from the $\mathbf{2 0 1 6}$ pedestrian survey at Adair-Steadman (41FS2).

\begin{tabular}{|c|c|c|c|c|c|c|}
\hline $\begin{array}{c}\text { Catalog } \\
\text { Number } \\
\text { (TTU-A7-) }\end{array}$ & Material & Source & $\begin{array}{c}\text { Dimensions } \\
\left(\mathbf{m m}^{*}\right)\end{array}$ & $\begin{array}{c}\text { Platform } \\
\text { Type }\end{array}$ & $\begin{array}{c}\text { Platform } \\
\text { Dimensions } \\
\left(\mathbf{m m}^{*}\right)\end{array}$ & Count \\
\hline 67796 & chert & $\begin{array}{c}\text { Edwards } \\
\text { Formation }\end{array}$ & $12.61,10.53,1.58$ & Flat & $4.04,1.59$ & 1 \\
\hline 67794 & chert & $\begin{array}{c}\text { Edwards } \\
\text { Formation }\end{array}$ & $14.94,20.57,6.74$ & Crushed & $\mathrm{n} / \mathrm{a}$ & 1 \\
\hline Total & & & & & & $\mathbf{2}$ \\
\hline
\end{tabular}

* length, width, thickness 
Table 6. Debris recovered from the 2016 pedestrian survey at Adair-Steadman (41FS2).

\begin{tabular}{|c|c|c|c|c|}
\hline $\begin{array}{c}\text { Catalog Number } \\
\text { (TTU-A7-) }\end{array}$ & Material & Source & $\begin{array}{c}\text { Dimensions } \\
\left(\mathbf{m m}^{*}\right)\end{array}$ & Count \\
\hline 67795 & chert & Edwards Formation & $13.94,13.39,2.82$ & 1 \\
\hline 67790 & chert & Edwards Formation & $27.69,39.11,6.58$ & 1 \\
\hline 67792 & chert & Edwards Formation & $8.93,8.87,0.84$ & 1 \\
\hline 67793 & chert & Edwards Formation & $6.33,7.43,1.13$ & 1 \\
\hline 67789 & chert & Edwards Formation & $14.59,16.83,1.78$ & 1 \\
\hline 67788 & chert & Edwards Formation & $27.64,11.43,5.34$ & 1 \\
\hline Total & & & & 6 \\
\hline
\end{tabular}

* length, width, thickness

Biface TTU-A7-67791 (Figure 7; Table 7) was a mid-section of a bifacial core or tool. It was completely flaked on both sides with no cortex remaining.
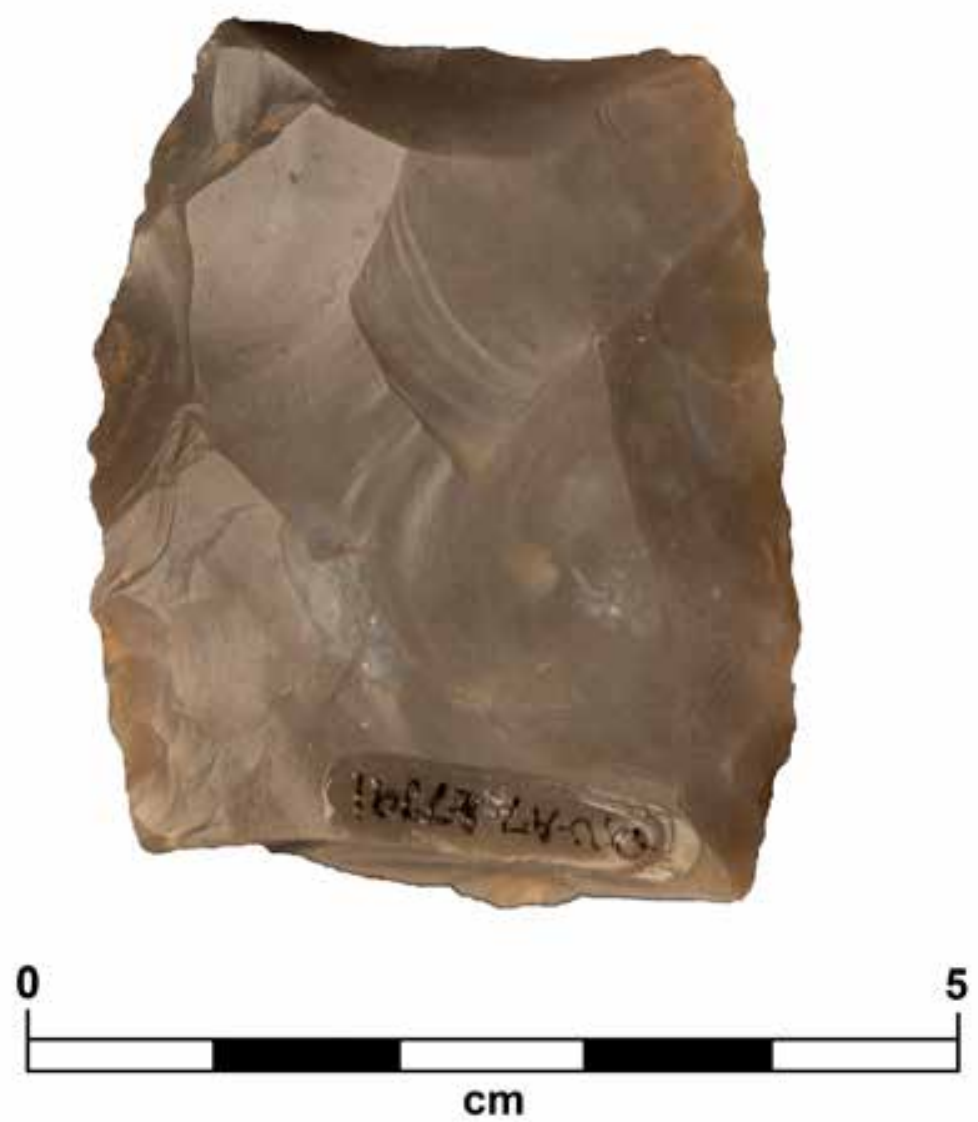

Figure 7. A biface (TTU-A7-67791) found during the 2016 pedestrian survey at Adair-Steadman (41FS2). 
Table 7. Biface recovered from the 2016 pedestrian survey at Adair-Steadman (41FS2).

\begin{tabular}{|c|c|c|c|c|}
\hline $\begin{array}{c}\text { Catalog Number } \\
\text { (TTU-A7-) }\end{array}$ & Material & Source & $\begin{array}{c}\text { Dimensions } \\
\left(\mathbf{m m}^{*}\right)\end{array}$ & Count \\
\hline 67791 & chert & Edwards Formation & $43.62,36.50,11.23$ & 1 \\
\hline Total & & & & $\mathbf{1}$ \\
\hline
\end{tabular}

* length, width, thickness

2017 Field Season

A crew of three people completed a $100 \%$ pedestrian survey during the 1-day 2017 season. Seven lithic debitage were mapped and collected throughout the AdairSteadman site area (Figure 8; Tables 8-9). All seven (100\%) of the debitage were chert that was sourced to the Edwards Formation.

The debitage consisted of four flakes and three pieces of debris. The flake platforms were classified as flat $(n=2 ; 50 \%)$, abraded $(n=1 ; 25 \%)$, and crushed $(n=1$; $25 \%)$. The presence of both abraded and flat platforms indicated that these flakes were detached from both bifacial and blocky core types (e.g., Andrefsky, 1998).

Over a span of 45 minutes (from $12: 15 \mathrm{pm}$ to $12: 45 \mathrm{pm}$ ), a UAV was flown over Adair-Steadman and a total of 135 overlapping aerial images were captured. These images then were imported into Agisoft Metashape photogrammetry software on an iMac computer at the Landmark's Quaternary Research Center. From these images, a dense point cloud was created consisting of $34,493,855$ points (Figure 9). From the dense cloud data, a high resolution digital elevation model then was interpolated within Metashape with an output resolution of 6,099x8160 6.46 cm/pix (Figure 10). The last step was the creation of an orthomosaic map that seamlessly tiled aerial images together into a new georeferenced image with a resolution of $11182 \times 152683.23 \mathrm{~cm} / \mathrm{pix}$ (Figure 11). 


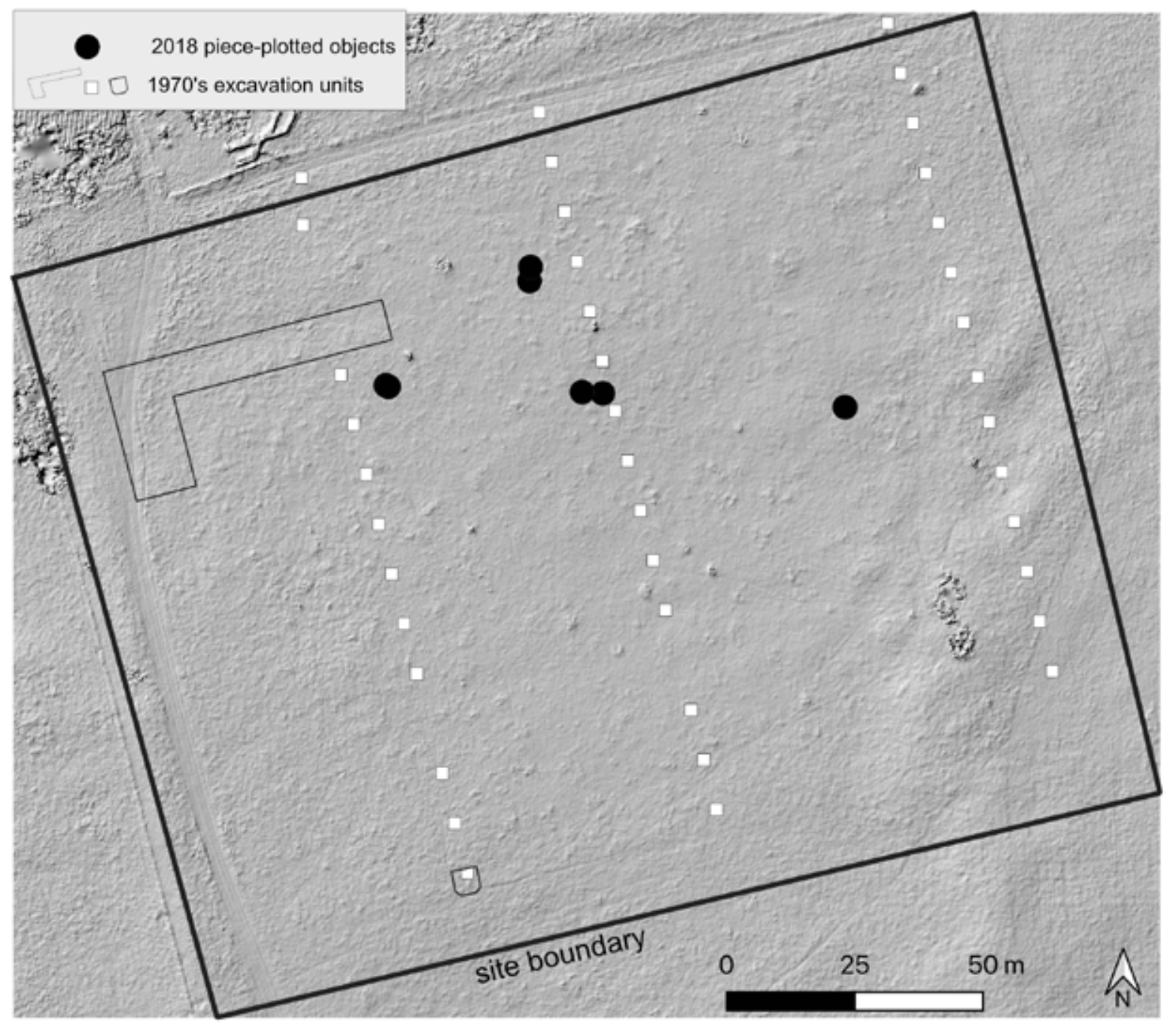

Figure 8. Location of piece-point-plotted lithic artifacts recovered during the 2017 pedestrian survey at Adair-Steadman (41FS2).

Table 8. Flakes recovered from the 2017 pedestrian survey at Adair-Steadman (41FS2).

\begin{tabular}{|c|c|c|c|c|c|c|}
\hline $\begin{array}{c}\text { Catalog } \\
\text { Number } \\
\text { (TTU-A7-.) }\end{array}$ & Material & Source & $\begin{array}{c}\text { Dimensions } \\
\left(\mathbf{m m}^{*}\right)\end{array}$ & $\begin{array}{c}\text { Platform } \\
\text { Type }\end{array}$ & $\begin{array}{c}\text { Platform } \\
\text { Dimensions } \\
\left(\mathbf{m m}^{*}\right)\end{array}$ & Count \\
\hline 68698 & chert & Edwards Formation & $\begin{array}{c}19.87,22.32, \\
9.19\end{array}$ & flat & $18.83,10.32$ & 1 \\
\hline 68701 & chert & Edwards Formation & $\begin{array}{c}13.58,21.28, \\
3.41\end{array}$ & abraded & $13.18,3.72$ & 1 \\
\hline 68697 & chert & Edwards Formation & $\begin{array}{c}18.69,17.66, \\
3.93\end{array}$ & crushed & $\mathrm{n} / \mathrm{a}$ & 1 \\
\hline 68702 & chert & Edwards Formation & $\begin{array}{c}12.07,14.77, \\
2.77\end{array}$ & flat & $10.63,3.49$ & 1 \\
\hline Total & & & & & & $\mathbf{4}$ \\
\hline
\end{tabular}

* length, width, thickness 
Table 9. Debris recovered from the 2017 pedestrian survey at Adair-Steadman (41FS2).

\begin{tabular}{|c|c|c|c|c|}
\hline $\begin{array}{c}\text { Catalog Number } \\
\text { (TTU-A7-) }\end{array}$ & Material & Source & Dimensions (mm*) & Count \\
\hline 68703 & chert & Edwards Formation & $42.48,21.21,21.54$ & 1 \\
\hline 68700 & chert & Edwards Formation & $8.51,12.55,4.97$ & 1 \\
\hline 68699 & chert & Edwards Formation & $23.41,21.37,6.46$ & 1 \\
\hline Total & & & & $\mathbf{3}$ \\
\hline
\end{tabular}

* length, width, thickness

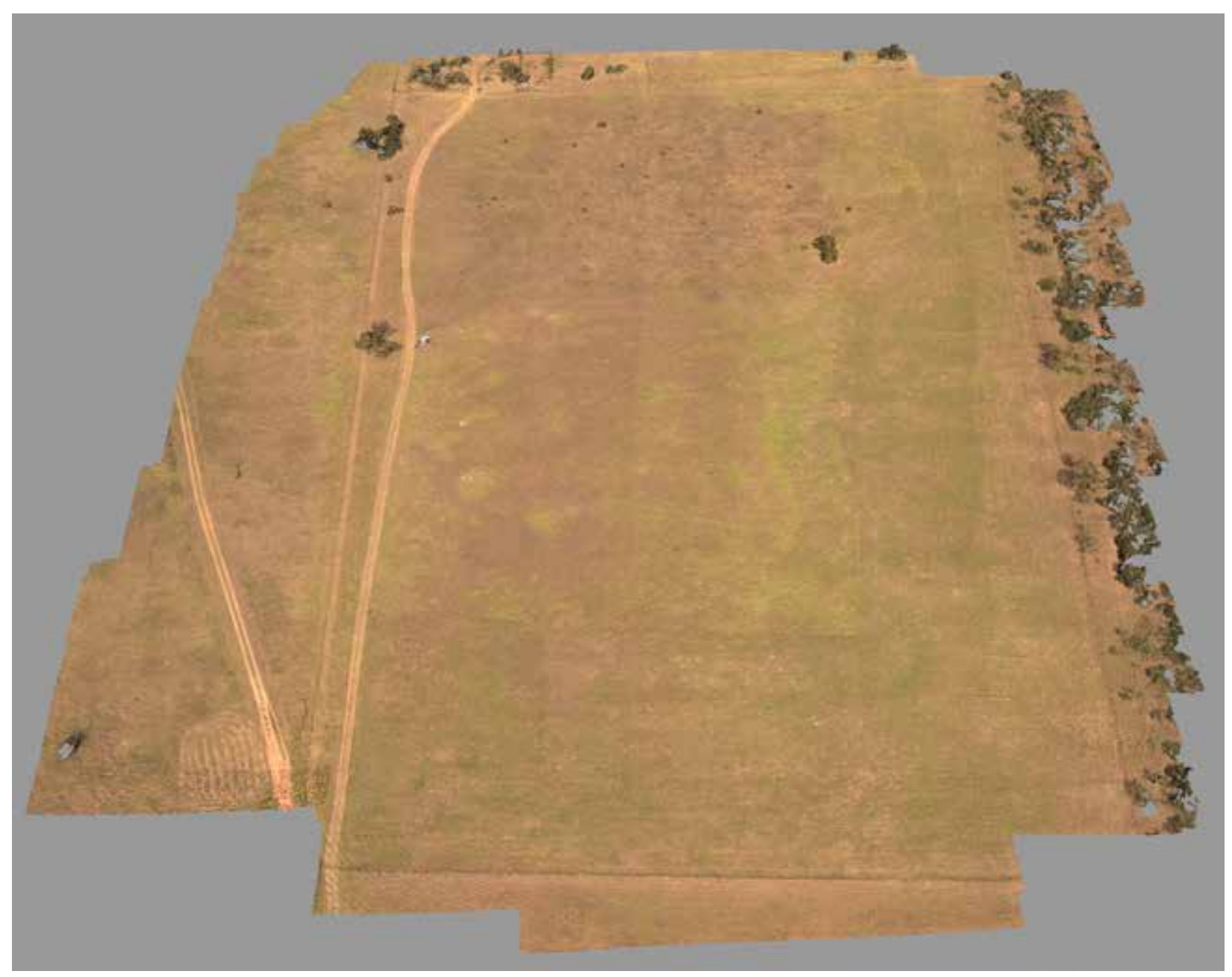

Figure 9. A dense cloud model of the Adair-Steadman (41FS2) site.

2018 Field Season

A crew of four people completed a $100 \%$ pedestrian survey during the 1 -day 2018 season. Six lithic debitage were mapped and collected throughout the AdairSteadman site area (Figure 12; Tables 10-11). Five pieces of debitage (60\%) were chert that was sourced to the Edwards Formation. One piece $(20 \%)$ of debitage was 
chert that was sourced to the Ogallala Formation gravels. The debitage consisted of three flakes and three pieces of debris. The flake platforms were classified as abraded $(n=2 ; 67 \%)$ and flat $(n=1 ; 33 \%)$. The presence of both abraded and flat platforms indicated that these flaked were detached from both bifacial and blocky core types (e.g., Andrefsky, 1998).

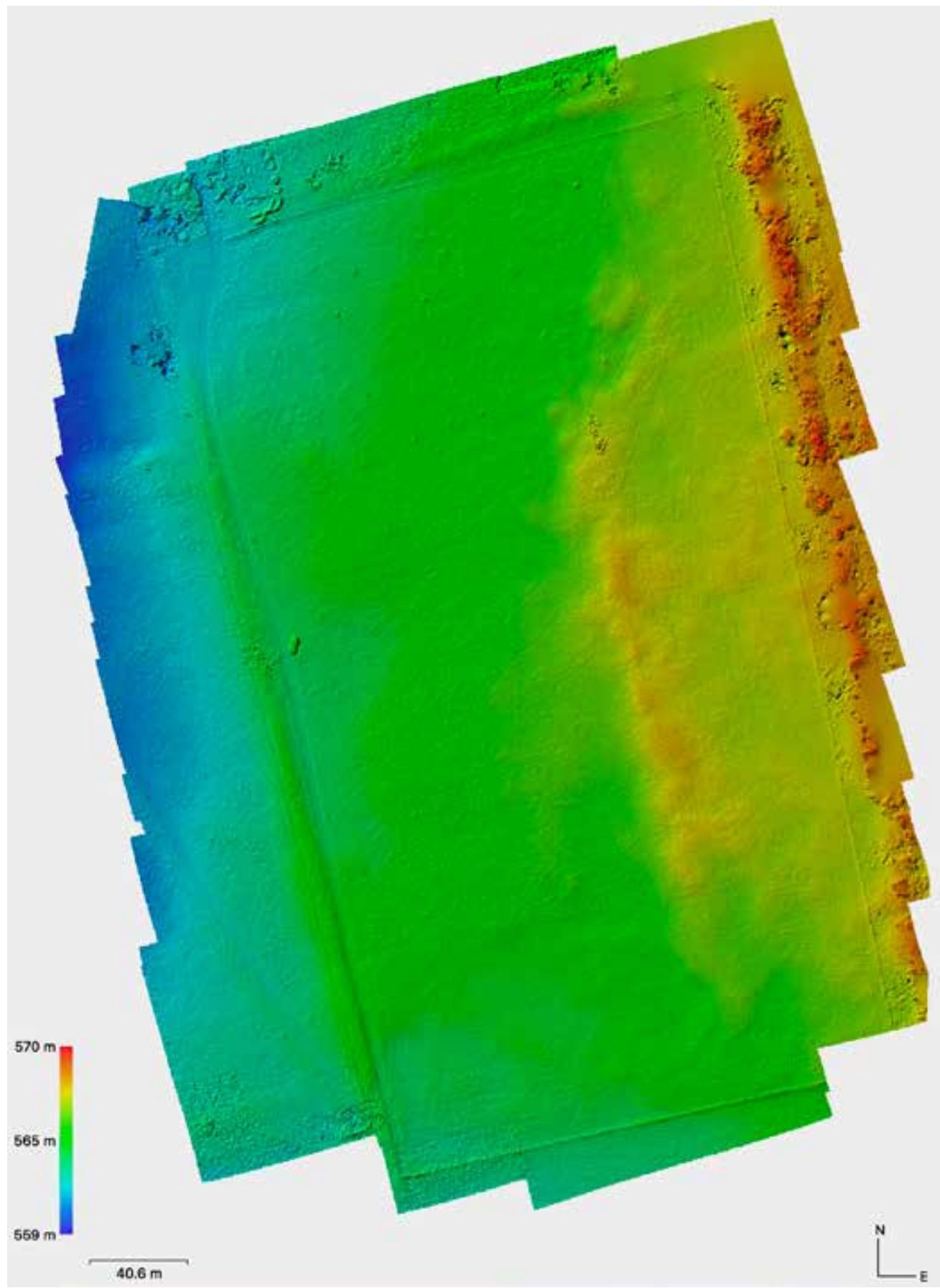

Figure 10. A digital elevation model of the Adair-Steadman (41FS2) site. 


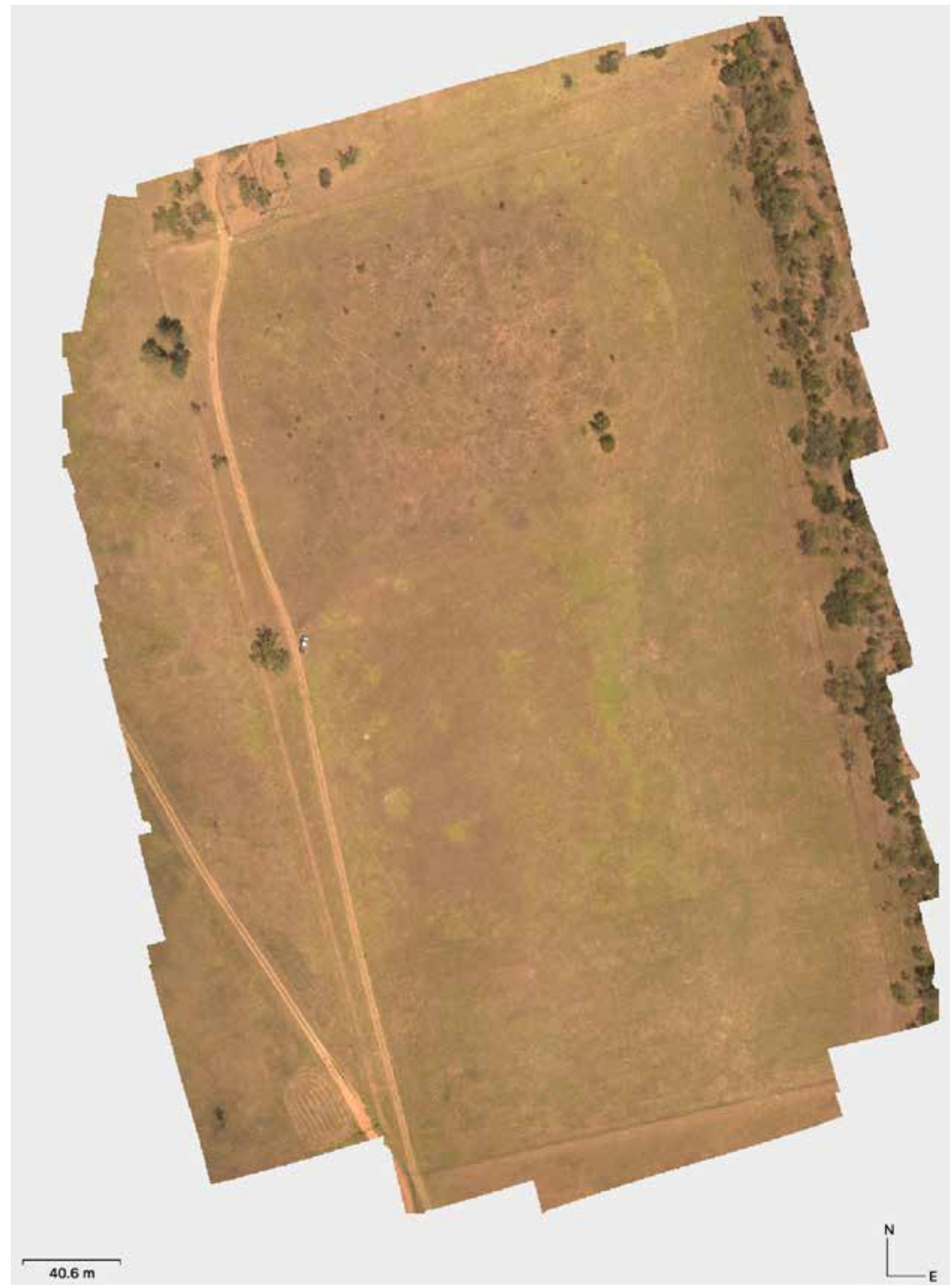

Figure 11. An orthomosiac model of the Adair-Steadman (41FS2) site. 


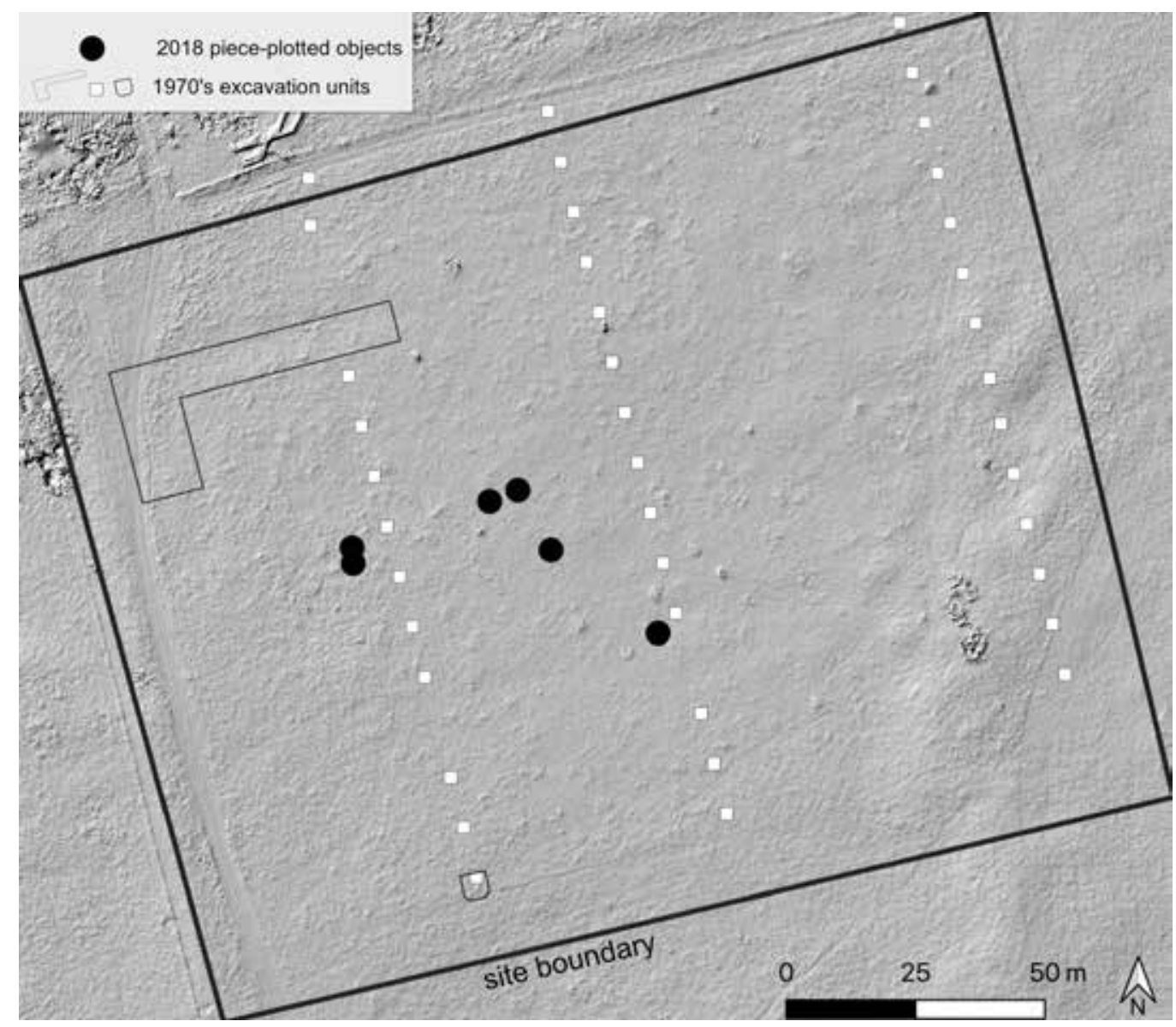

Figure 12. Location of piece-point-plotted lithic artifacts recovered during the 2018 pedestrian survey at Adair-Steadman (41FS2).

Table 10. Flakes recovered from the 2018 pedestrian survey at Adair-Steadman (41FS2).

\begin{tabular}{|c|c|c|c|c|c|c|}
\hline $\begin{array}{c}\text { Catalog } \\
\text { Number } \\
\text { (TTU-A7-) }\end{array}$ & Material & Source & $\begin{array}{c}\text { Dimensions } \\
(\mathbf{m m} \boldsymbol{*})\end{array}$ & $\begin{array}{c}\text { Platform } \\
\text { Type }\end{array}$ & $\begin{array}{c}\text { Platform } \\
\text { Dimensions } \\
\left(\mathbf{m m}^{*}\right)\end{array}$ & Count \\
\hline 69452 & chert & Edwards Formation & $31.13,22.47,6.3$ & abraded & $18.15,5.94$ & 1 \\
\hline 69451 & chert & Ogallala Formation & $24.7,18.07,4.8$ & flat & $8.45,3.83$ & 1 \\
\hline 69453 & chert & Edwards Formation & $35.28,24.01,3.48$ & abraded & $3.11,1.29$ & 1 \\
\hline Total & & & & & & $\mathbf{4}$ \\
\hline
\end{tabular}

* length, width, thickness

Table 11. Debris recovered from the 2018 pedestrian survey at Adair-Steadman (41FS2).

\begin{tabular}{|c|c|c|c|c|}
\hline $\begin{array}{c}\text { Catalog Number } \\
\text { (TTU-A7-) }\end{array}$ & Material & Source & $\begin{array}{c}\text { Dimensions } \\
\left(\mathbf{m m}^{*}\right)\end{array}$ & Count \\
\hline 69456 & chert & Edwards Formation & $29.94,35.95,10.4$ & 1 \\
\hline 69455 & chert & Edwards Formation & $8.63,10.08,3.07$ & 1 \\
\hline 69454 & chert & Edwards Formation & $8.63,10.08,1.07$ & 1 \\
\hline Total & & & & $\mathbf{3}$ \\
\hline
\end{tabular}

* length, width, thickness 
2019 Field Season

A crew of two people completed a 100\% pedestrian survey during the 1-day 2019 season. No objects were found during survey. A thunderstorm that had just finished precipitated a significant amount of rainfall onto to the site prior to the survey. The rain most likely impacted the ability to view lithic material on the surface.

Spatial Analysis

The spatial distribution of lithic artifacts $(n=47)$ recovered from the 2015-2019 season pedestrian surveys was examined in relationship to objects $(n=407)$ collected from previous survey work between 1999-2014 (MacEwen et al., 2006; Hurst and Johnson, 2012, 2016; Figure 13). A spatial cluster analysis was used to ascertain if any additional concentrations of lithic material might suggest the location of new activity areas.

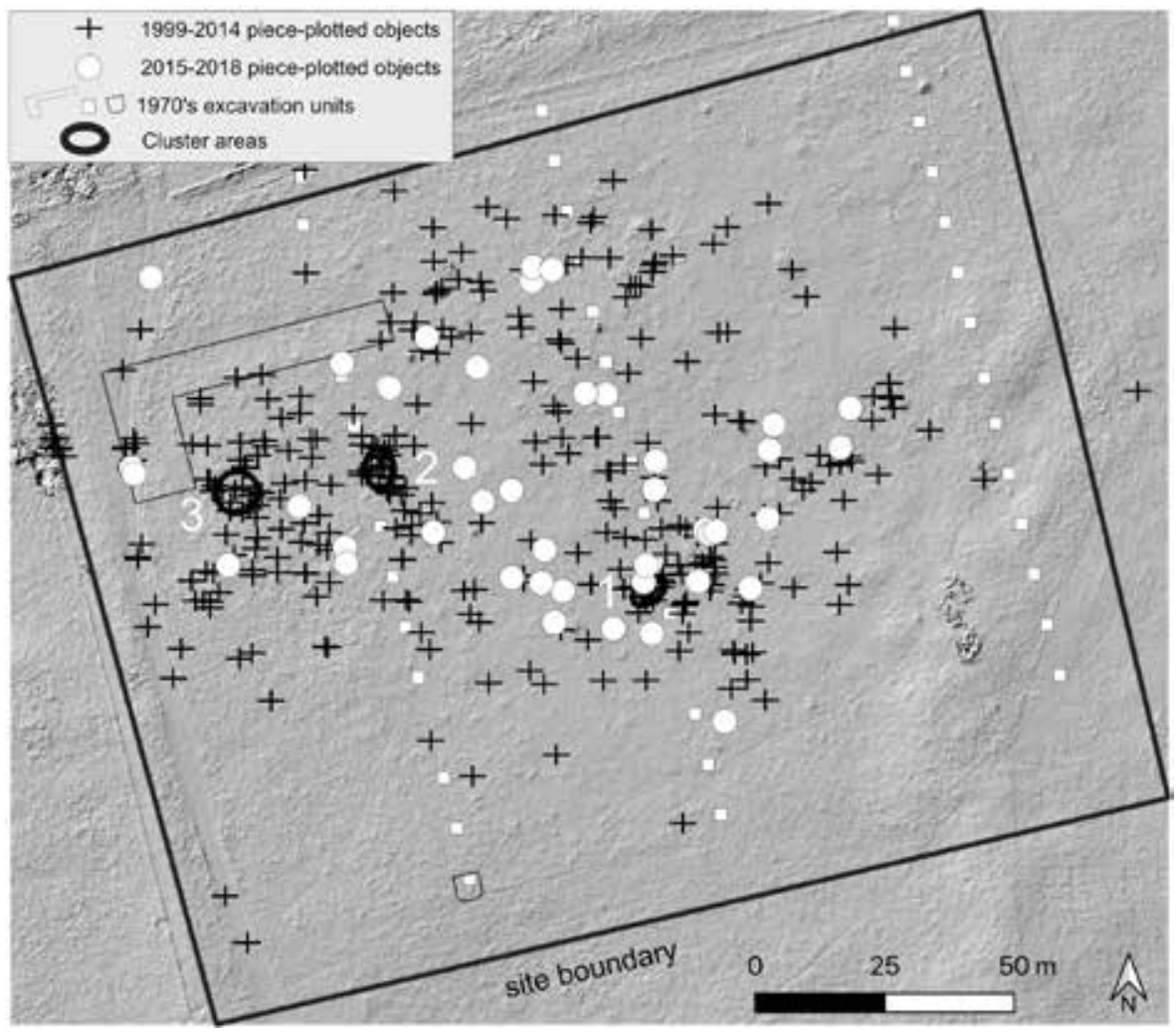

Figure 13. Lithic cluster analysis of objects found during the 1999-2014 and 20152019 pedestrian survey at Adair-Steadman (41FS2). 
Overall, no change occurred in the locations of where objects were found during survey between 2015-2019 in comparison to the previous years (1999-2014). This result meant that through the years materials were wording out throughout the site. Results of the cluster analysis identified three lithic concentration areas that contained 10 or more objects within a $5 \mathrm{~m}$ area (Figure 13). Concentration areas 1 and 2 were identified previously based on the spatial distribution of lithic material collected between 19992004 (Hurst and Johnson, 2016). These first two concentration areas were excavated between 2011-2013 (Hurst and Johnson, 2016). The third concentration area was new with the addition of the 2015-2019 lithic material. In future work, subsurface testing in this area will explore if any intact activity features exist at this location.

\section{Optical Stimulated Luminescence (OSL) dating}

Four sediment samples were collected and sent to the University of Washington's Luminescence Lab to be dated using the OSL method by Dr. James Feather in 2013 (Hurst and Johnson, 2016). Dating of these samples was completed in 2016. Test excavation at Adair-Steadman from 2011-2013 in unit 36N11E uncovered a clay band that consisted of a layer of lamellae within sandy sediments. Clay bands were a pedogenic feature that is characteristic of soils formed in sand (Holliday, 2004:112).

The presence of the clay band in the Adair-Steadman dune indicated that the dune had remained stable at some point in time in order for the clay to accumulate as a layer. To test this hypothesis, OSL samples were collected above and below the clay band (Figures 14,15). This unit was chosen for sampling because it was the most deeply excavated unit.

The OSL samples were collected by hammering light-tight PVC cylinders into the side of the test-unit profile (e.g., Feathers et al., 2006). A wooden block was used to buffer the impact of hammer blows at the end of the pipe. Both ends of the PVC cylinders were capped and tapped to ensure the sediment samples were not impacted by light. 


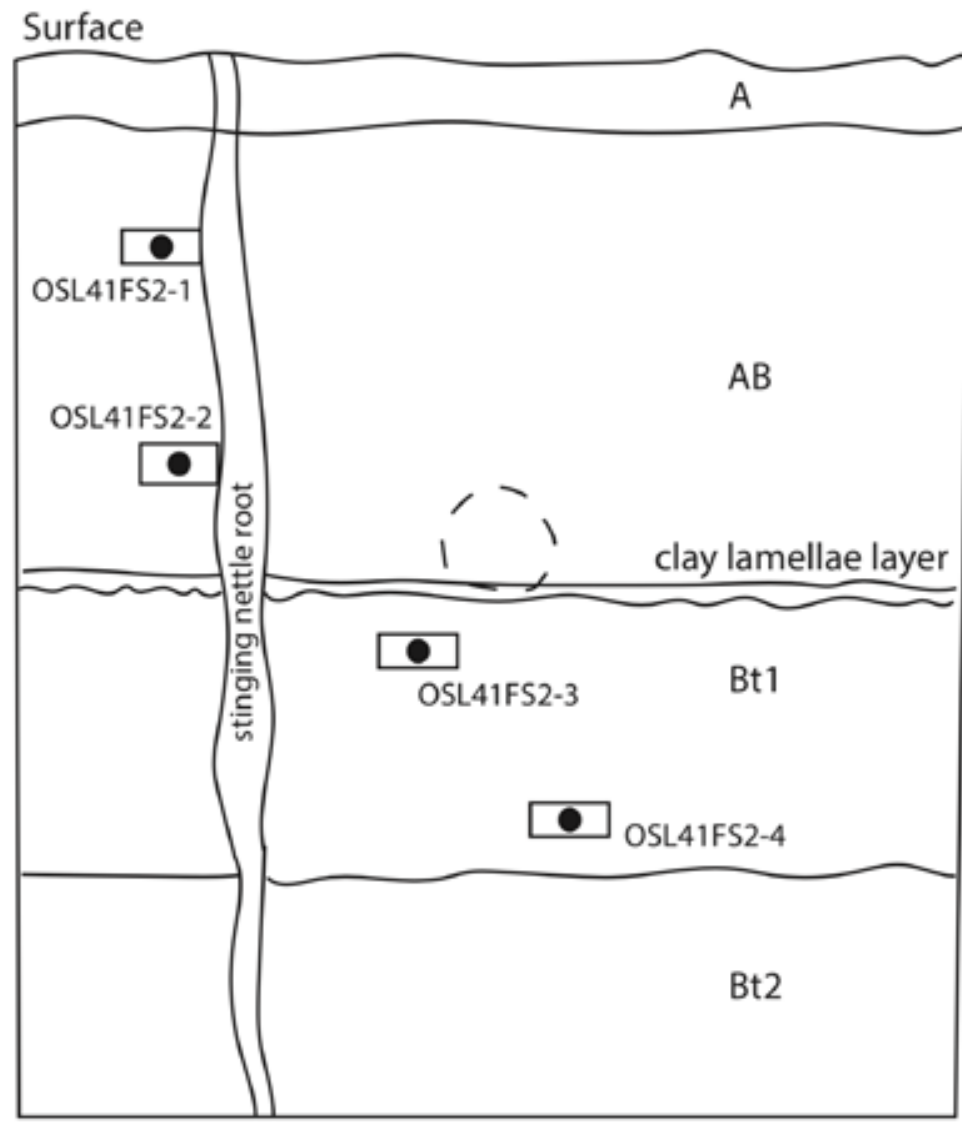

41FS2

West Wall Profile

$36 \mathrm{~N} 21 \mathrm{~W}$

- OSL sample

$\square$ OSL surrounding sediment sample

1 - Krotovena

Bottom of Excavation

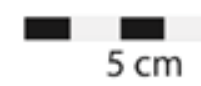

Figure 14. Profile drawing of OSL sampling areas - west wall excavation unit $36 \mathrm{~N}$ $21 \mathrm{~W}$ at Adair-Steadman (41FS2).

Optical stimulated luminescence was applied to $180-212 \mu \mathrm{m}$ quartz grains. The sensitivity of the quartz grains was not high resulting in equivalent dose values of UW $3016(n=54)$, UW $3017(n=63)$, UW 3018 (63), and UW 3019 (60). The average acceptance rate was $5.4 \%$, and sample UW 3016 was lower at $3.7 \%$ due to its location closer to the surface. All of the samples were bi or tri modal either from mixing or partial bleaching (Figures 16, 17, 18, and 19).

The youngest grains represented by the first component was 20th-century in age for UW2016 and a 500 year age for UW3019. The first component of these samples were likely sand grains being transported downward from the surface. 
In all of the samples, the second and third components were distinct, with no higher precision points between them. Very old grains were represented by the third and fourth components. These older grains within the sample were likely derived from upward admixture of grains from a lower stratum. A likely source for the third component of sample UW3016 is from upward movement of sand grains from the lower sand layers below the clay lamellae.

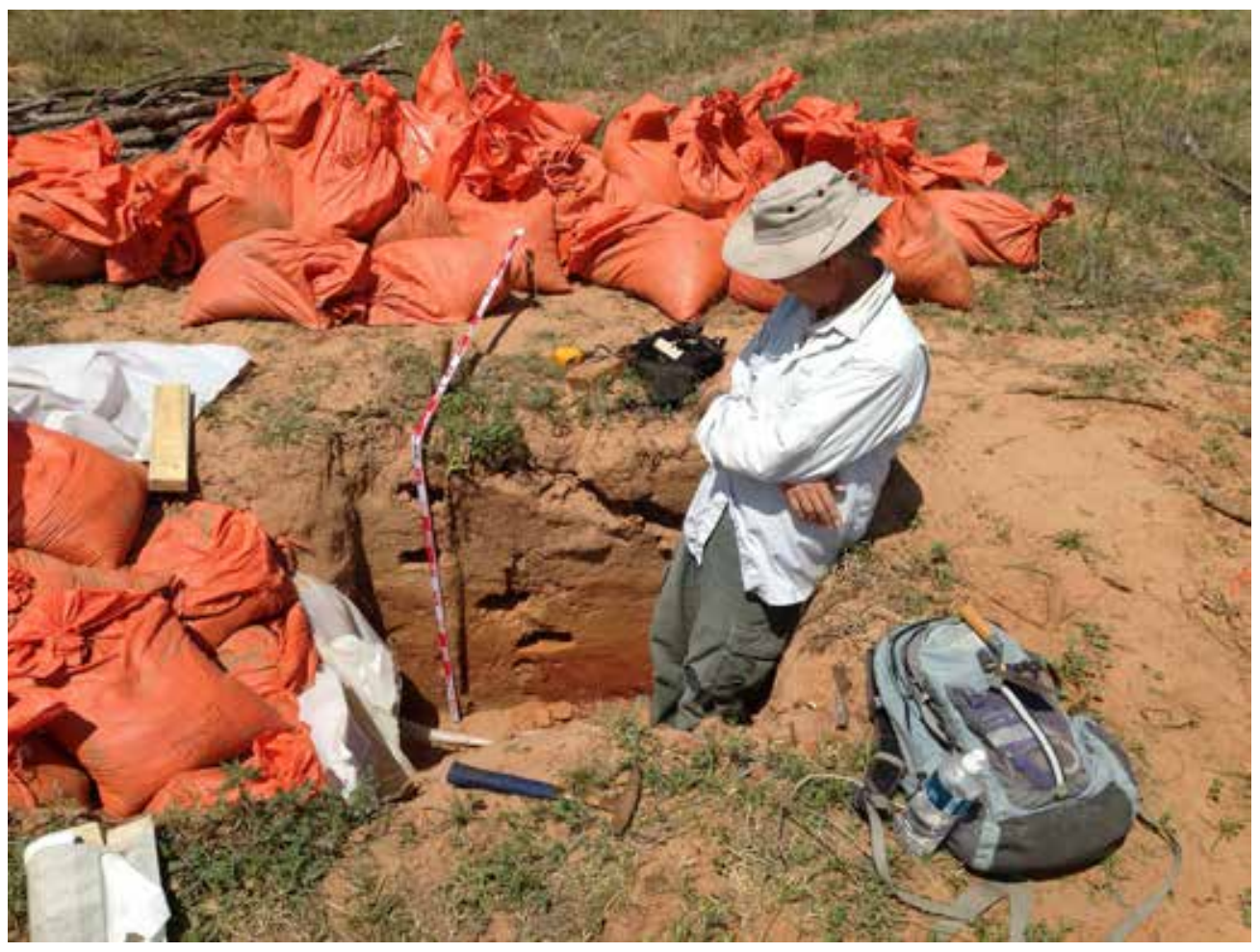

Figure 15. Dr. Vance Holiday removing OSL samples - west wall excavation unit $36 \mathrm{~N} 21 \mathrm{~W}$ at Adair-Steadman (41FS2).

The second component, therefore, likely represents the depositional age of the sediment layers at Adair-Steadman, and these are the accepted OSL ages. A clear distinction exists between ages from above and below the clay lamellae layer. The two upper samples are dated to the late Holocene with ages of $600 \pm 80$ (UW 3016) and 2,320 \pm 870 (UW3017) years. In contrast, the two lower samples, below the clay lamellae layer, are dated to the middle Holocene with ages of 6,900 \pm 700 (UW3018) and 6,430 \pm 640 (UW3019; Figure 20, Table 12) years. The two lower sample dates, however, are out of chronological order, but the dates were statistically indistinguishable due to their high calculated errors. 


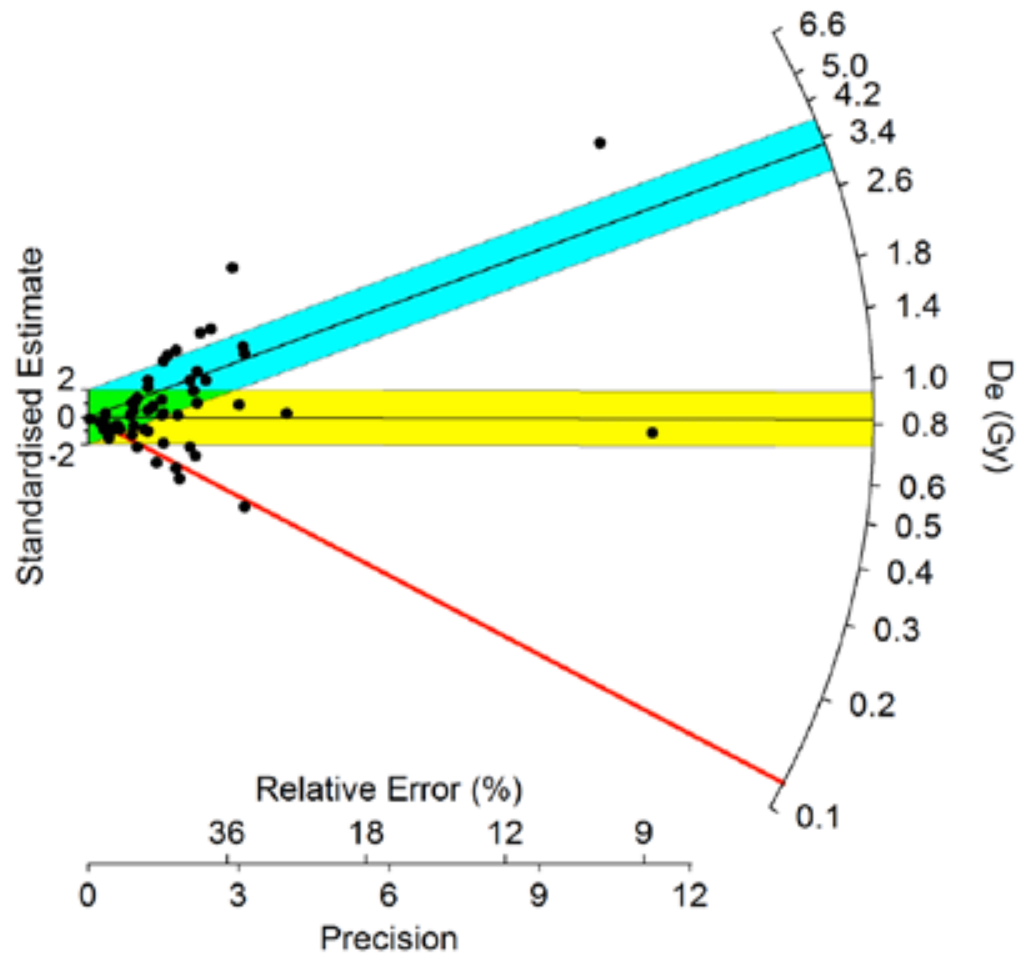

Figure 16. Radial graph of single-grain DE's of OSL sample UW3016 - west wall excavation unit 36N 21W at Adair-Steadman (41FS2).
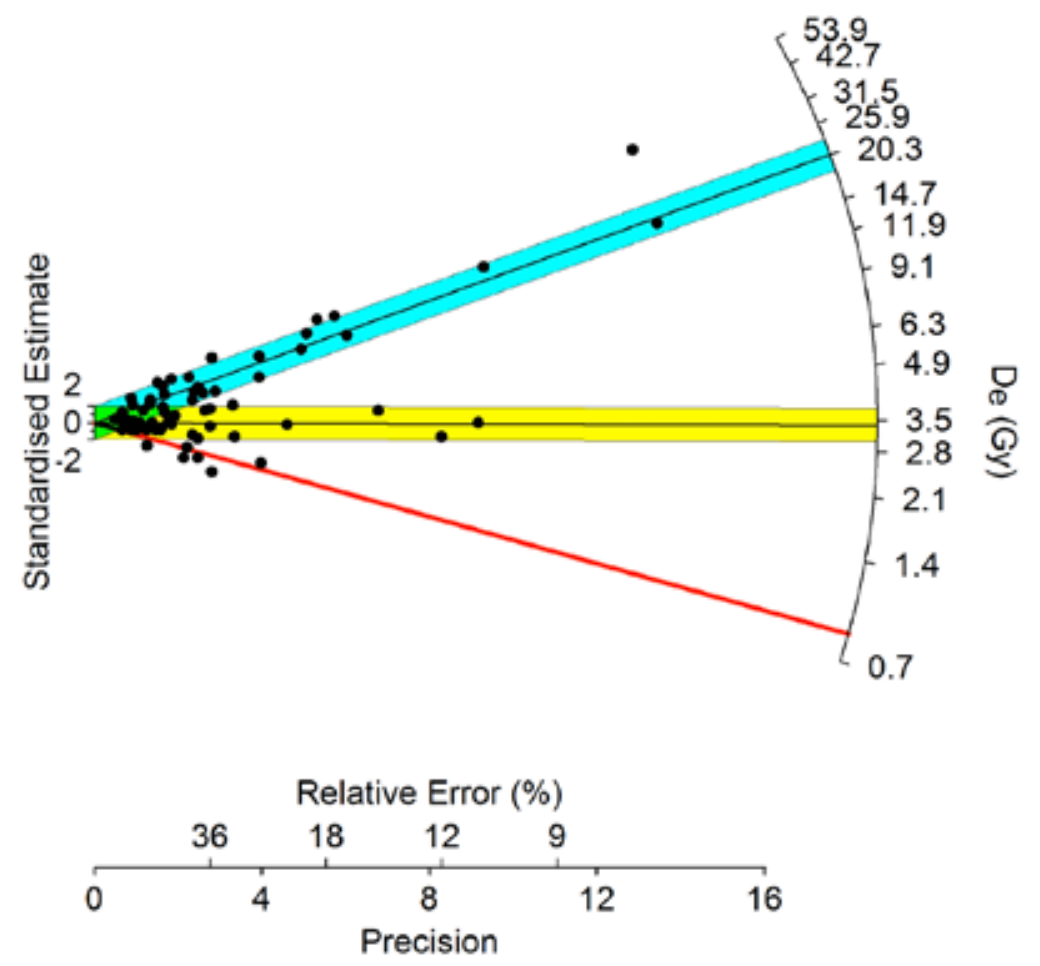

Figure 17. Radial graph of single-grain DE's of OSL sample UW3017 - west wall excavation unit 36N 21W at Adair-Steadman (41FS2). 


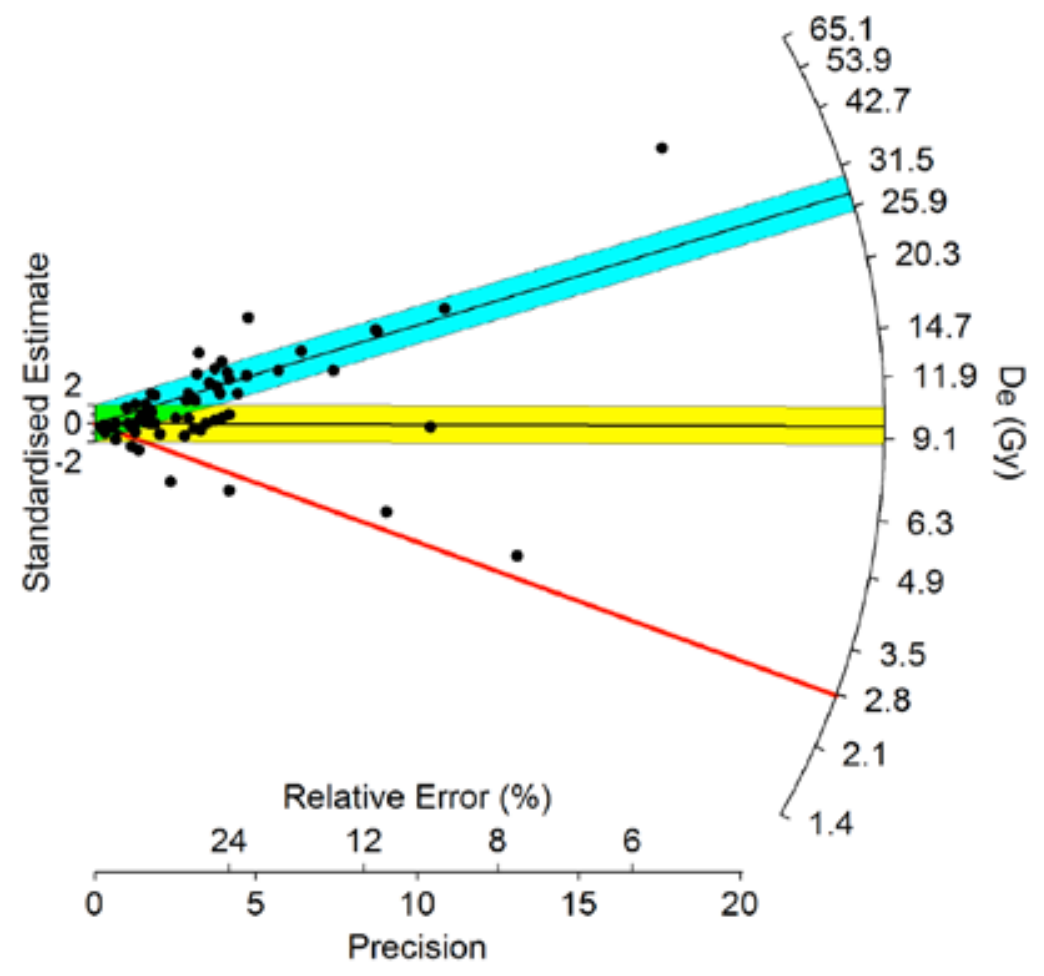

Figure 18. Radial graph of single-grain DE's of OSL sample UW3018 - west wall excavation unit 36N 21W at Adair-Steadman (41FS2).

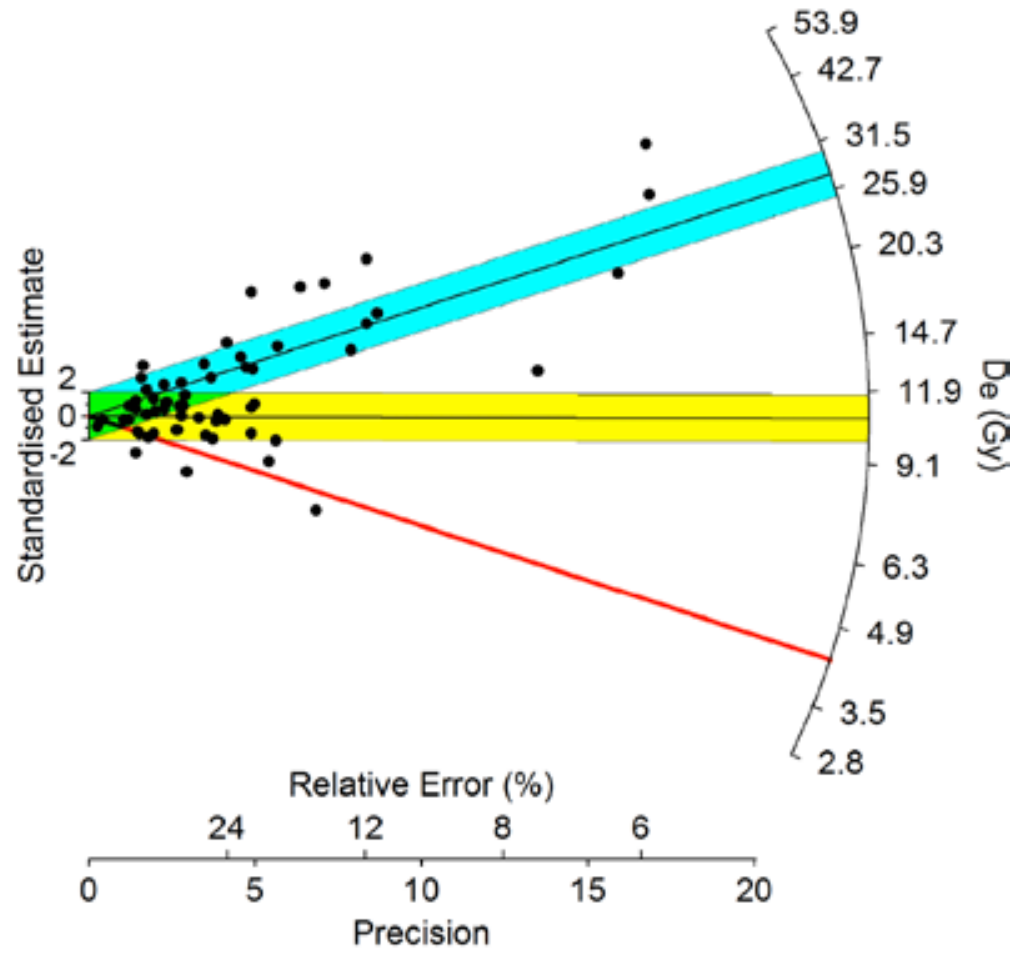

Figure 19. Radial graph of single-grain DE's of OSL sample UW3019 - west wall excavation unit 36N 21W at Adair-Steadman (41FS2). 


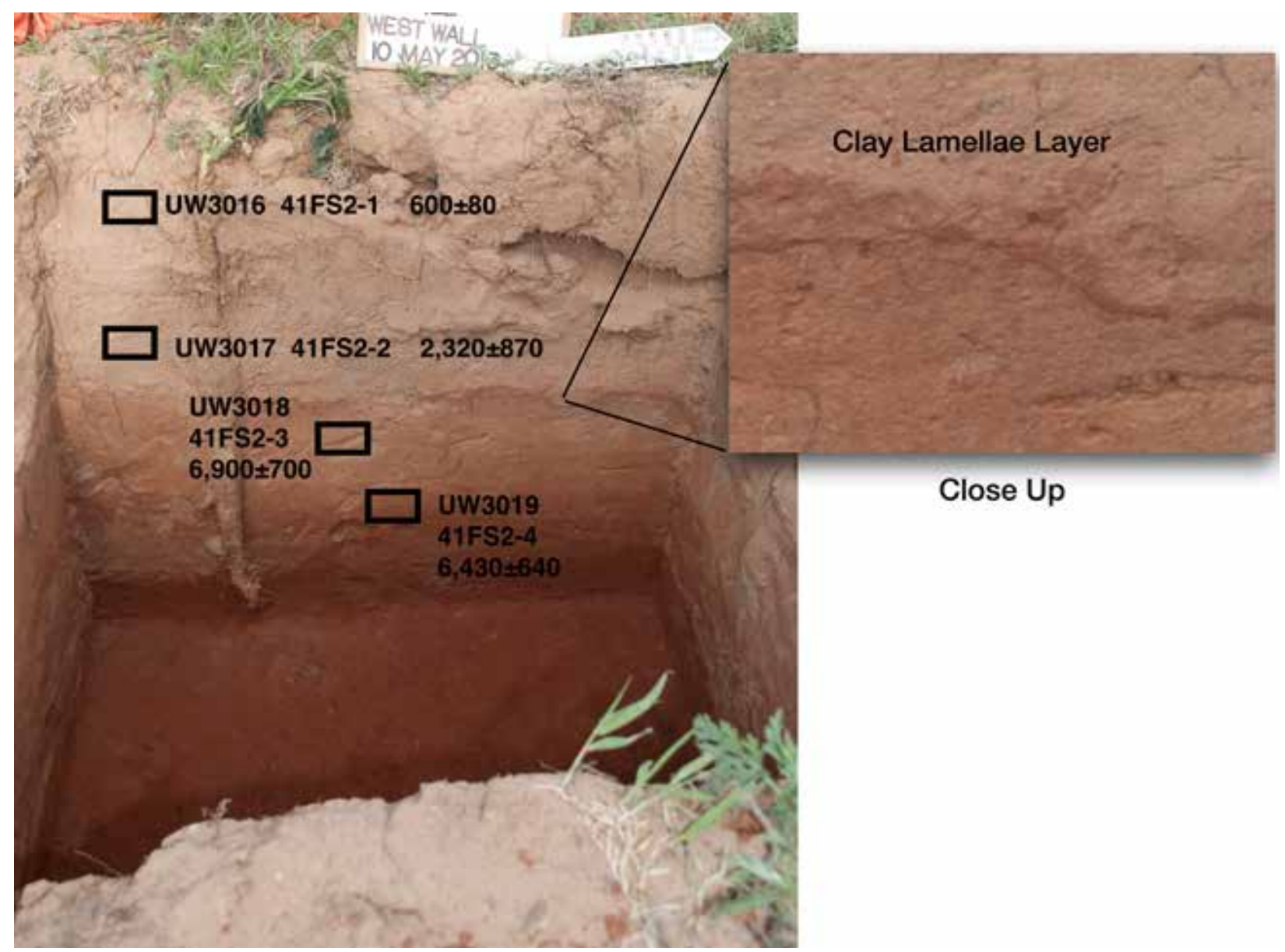

Figure 20. Location of OSL samples and ages - west wall excavation unit $36 \mathrm{~N}$ 21W at Adair-Steadman (41FS2).

Table 12. Optical Stimulated Luminescence results from the Adair-Steadman (41FS2) site.

\begin{tabular}{|c|c|c|}
\hline Sample Number & Depth (cm below surface) & OSL Age \\
\hline UW 3016 & 51 & $600 \pm 80$ \\
\hline UW 3017 & 87 & $2,320 \pm 870$ \\
\hline UW 3018 & 172 & $6,900 \pm 700$ \\
\hline UW 3019 & 202 & $6,430 \pm 640$ \\
\hline
\end{tabular}

OSL ages

Sample, Depth, component Upper Sand Layer UW 3016, .51 m, 600 \pm 80 UW 3017, $.87 \mathrm{~m}, \pm 2,320 \pm 870$ Lower Sand Layer UW3018 $1.726,900 \pm 700$ UW3019 $2.026,430 \pm 640$ 
The age of the UW3019 sample possibly may be underestimated. This sample was the only one with no high precision points within the accepted second component. A slightly older high precision point occurred, and if accepted, would adjust sample UW3019's age to 8,600 years. Accepting this older high precision point into the age calculation, however, would place too much weight into this one data point. Further work would be needed to clarify the age of the lower portion of the dune.

\section{DISCUSSION}

Field work and analysis from $2015-2019$ at Adair-Steadman is providing new insights into this hunter-gatherer campsite. A total of 47 lithic artifacts have been recorded on the surface over the past five years. Continued erosion of the site exposes new artifacts on the surface each year, although that number is decreasing through time. The last five-year total recovery rate is lower than the number of lithic artifacts mapped from 2010-2014 ( $n=104$; Hurst and Johnson, 2016a), 2005-2009 ( $n=151$; Hurst and Johnson, 2012), and 1999-2004 ( $n=154$; McEwen et al., 2006). Survey, nevertheless, has been successful in monitoring site erosion and the mapping and collecting of lithic artifacts on an annual basis.

The spatial distribution of artifacts mapped and collected over the past 21 years has defined three concentration areas. Two of these concentration areas were investigated through test excavation (Hurst and Johnson, 2016a). A new concentration area was identified with the addition of the 2015-2019 collected objects. This new concentration area would be slated for test excavation in the next five-year period.

The OSL results indicate that the sediments at Adair-Steadman were middle $(\sim 6,900$ years) to late Holocene ( $\sim 60$ years) in age. Further work is needed to clarify the age of the lower sediment below the clay lamellae layer, however, due to the potential impact of bioturbation. The OSL sediment samples directly below and above the clay lamellae layer were dated to $\sim 6,430$ years and $\sim 2,320$ years. These results indicate that the clay band is a stratigraphic marker and could be used to distinguish 
sediments deposited during the late Holocene across the site (i.e., sediments above the clay band).

The OSL dates do not provide an age for the Folsom occupation at AdairSteadman. The discovery of Folsom objects on the surface at Adair-Steadman (Hurst and Johnson 2016b) suggests that bioturbation has impacted greatly the vertical distribution of Folsom objects. This situation suggests it may be difficult to find an intact Folsom occupational surface at Adair-Steadman.

\section{CONCLUDING REMARKS}

The investigation of Adair-Steadman (41FS2) during the 2015-2019 field seasons consisted of annual survey and mapping with a UAV drone. Dating OSL sediment samples collected in 2013 was completed in 2016. Survey results indicated that artifacts continue to be exposed. The lower number of objects found in the last five years, however, suggests the rate of erosion has slowed.

The results of OSL dating indicate that the clay band in the Adair-Steadman dune can be used as a stratigraphic marker to distinguish upper late Holocene deposits from lower middle Holocene sediments. The sediments below the lamellae layer, however, are not Folsom-age. Bioturbation has impacted the vertical distribution of Folsom artifacts at the site and finding an intact Folsom occupational surface at Adair-Steadman may be difficult. 



\section{Appendix A}

\section{HERITAGE LANDSCAPE MANAGEMENT AT ADAIR-STEADMAN 2015-2019}

Sterling Scott Trevey

Adair-Steadman is situated in the Rolling Plains of Texas, and like most of the region, suffers from a lack of natural fire frequency resulting in encroaching brush. Historically, fire plays an active role in shaping the landscape and reducing the density of brush species such as mesquite (Wright and Bailey, 1982). Honey mesquite (Prosopis glandulosa) has long been an invasive problem in the Southwest and a focus for management since the 1950s (Parker and Martin, 1952; Martin, 1975; Martin and Morton, 1993; Tiedemann and Klemmedson, 2004). Restoration and preservation efforts at Adair-Steadman focus on controlling the dense mesquite population.

Although mesquite is a native brush, it can become a serious problem for landowners when left unchecked from a management standpoint. Rangeland with a dense cover of mesquite competes with other native plants, reducing their numbers, and therefore, reducing the amount of available forage for domestic livestock and wildlife. It also competes for water, sunlight, and other nutrients beneficial to all species in a healthy rangeland ecosystem. From a cultural resource perspective, as the top growth of mesquite matures, so does its root system. As the root system matures, it impacts surface and subsurface cultural resources. Because of the archaeological sensitivity of the site, typical brush management methods cannot be used (e.g., rollerchopping, excavating, and the use of diesel in an herbicidal solution). Instead, methods used at the Lubbock Lake Landmark (Trevey and McEwen, 2012) that do not impact the archaeological resources are utilized at Adair-Steadman. The methods used at Adair Steadman are mechanical removal and herbicide applications. 
In 2006, mesquite populated most of the Adair-Steadman site (Trevey and McEwen, 2012). The Landmark historical maintenance team initially cleared out the landscape using a combination of archaeologically safe herbicides and non-subsurface disturbing mechanical techniques (Trevey and McEwen, 2012). Since 2006, mesquite at Adair-Steadman has been maintained through monitoring signs for new growth and applying herbicides as warranted.

Herbicide was once again was applied to re-sprouted mesquite as well as Hackberry, Scattered Sand Shinnery, Persimmon, Plains Prickly Pear, and Queens Delight on May 3rd, 2018 (Figures 21, 22). It was noticed while investigating the resprouted mesquite that diesel may have been used by the landowner to treat mesquite. The herbicide used was Sendero Herbicide (2 quartz), non ionic surfactant (1 quart), and blue dye (1 pint) mixed with 50 gallons of water. A total of 27 gallons of herbicide was used.

Continued work will keep the mesquite population under control to prevent surface and subsurface disturbance to the site. Yearly inspections at this site will be in order for the vegetation to continue to flourish as a native rangeland plant community, free of brush and invasive weed species. 


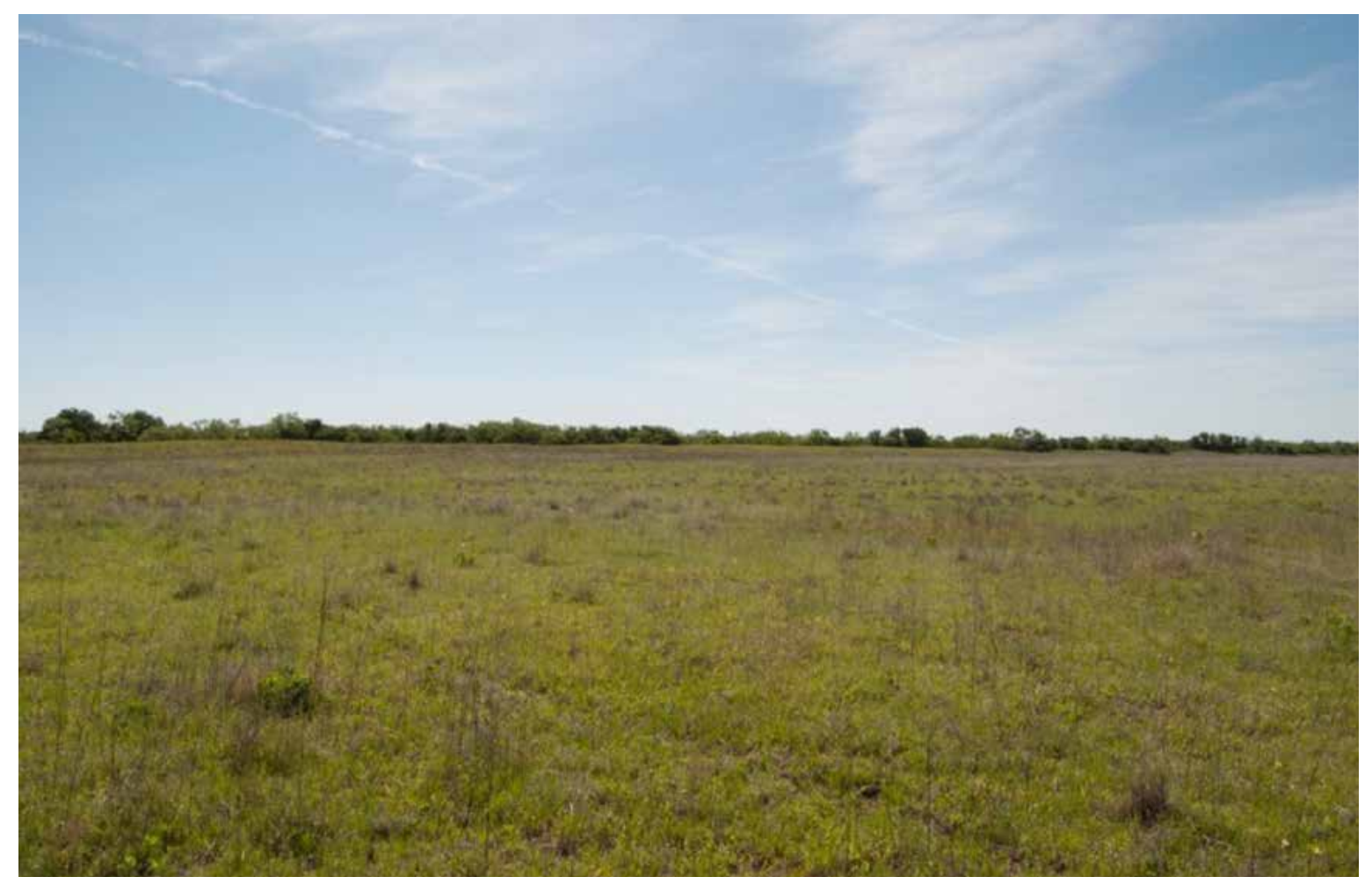

b

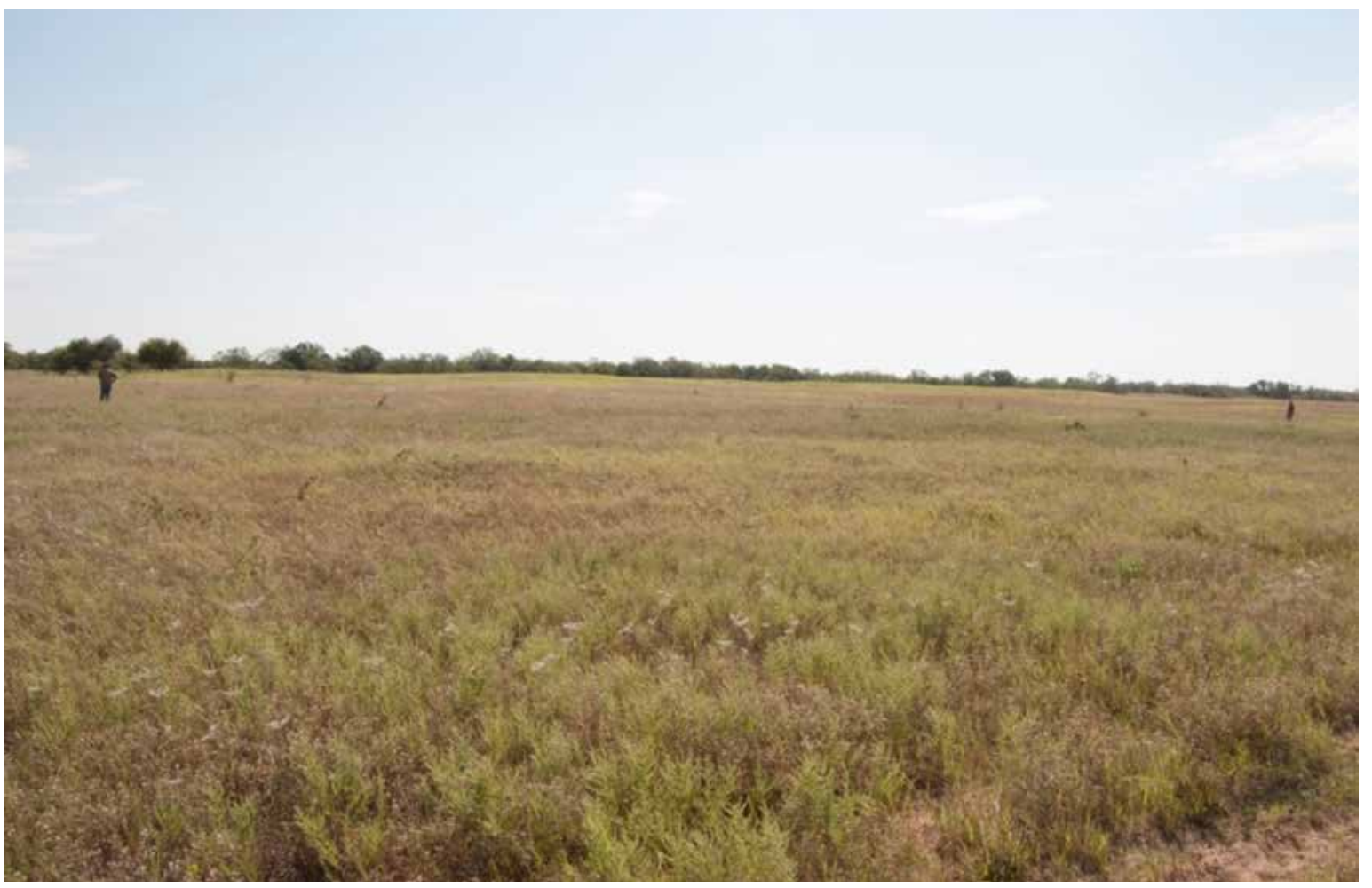

Figure 21. View from the east of Adair-Steadman vegetation: a) taken in April 2016 indicating some weedy growth within primarily a grassland setting (note the thick mesquite growth in the distance off of the site); b) taken in April 2017 indicating increase in weedy growth and sprouting of mesquite trees. 


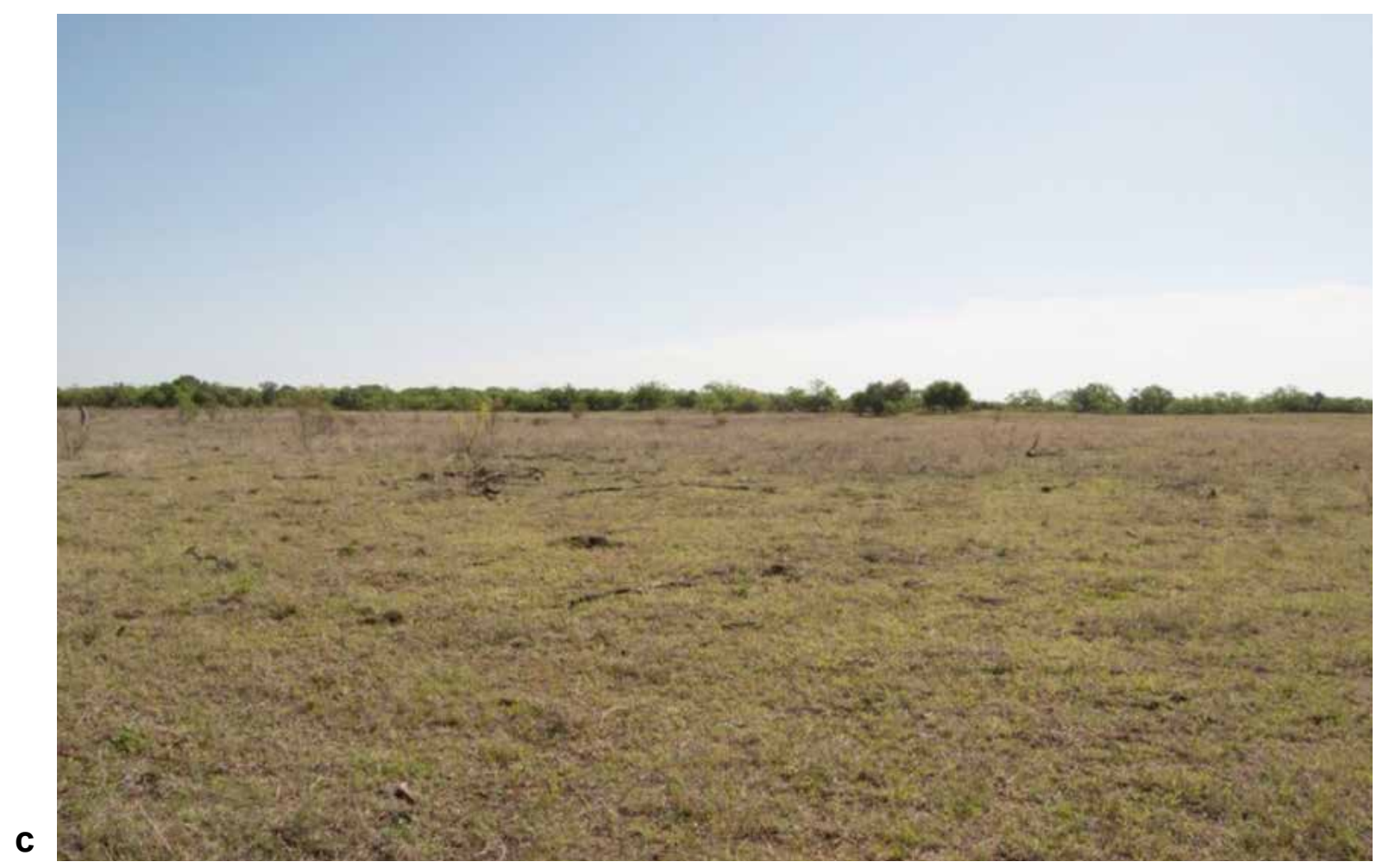

Figure 21 (Continued). View from the east of Adair-Steadman vegetation: c) taken in April 2018 indicating increased growth and number of young mesquite trees.

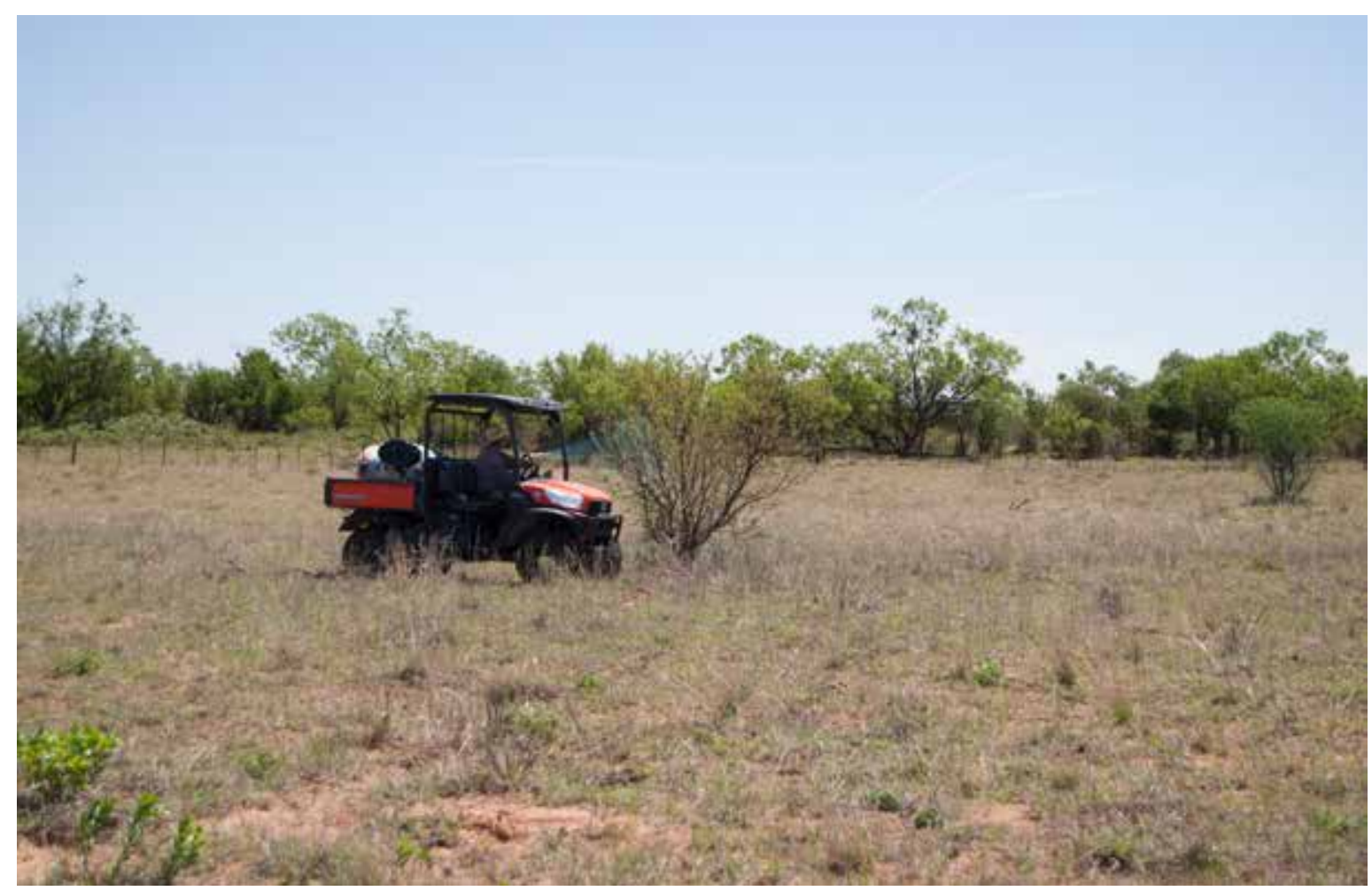

Figure 22. Applying herbicide on one of the mesquite trees at Adair-Steadman that had sprouted in 2016 to 2017. 


\section{REFERENCES CITED}

Andrefsky, William Jr.

1998 Lithics: Macroscopic Approaches to Analysis. Cambridge Manuals in Archaeology.

Cambridge University Press, Cambridge.

Baker, Victor R.

1983 Late-Pleistocene Fluvial Systems. In: Stephen C. Porter (ed.), The Late

Pleistocene, Late Quaternary Environments of the United States. Vol. 1, pp. 115-129.

University of Minnesota Press, Minneapolis.

Banks, Larry D.

1990 From Mountain Peaks to Alligator Stomachs: A Review of Lithic Sources in the Trans-Mississippi South, the Southern High Plains and Adjacent Southwest. Oklahoma Anthropological Memoir, 4:1-179.

Barry, R.G.

1983 Late-Pleistocene Climatology. In: Stephen C. Porter (ed.), The Late Pleistocene, Late Quaternary Environments of the United States. Vol. 1, pp. 390-407. University of Minnesota Press, Minneapolis.

Bettinger, Robert L. 1980 Explanatory/Predictive Models of Hunter-Gatherer Adaptation. In: Michael B.

Schiffer (ed.), Advances in Archaeological Method and Theory, 3:189-255. Academic Press, New York.

Bomar, George W.

1995 Texas Weather, 2nd edition. University of Texas Press, Austin.

Bryant, Vaughn M.

1977 A 16,000 Year Pollen Record of Vegetational Change in Central Texas.

Palynology, 1:143-156.

Cotterell, Brian and John Kamminga

1979 The Mechanics of Flaking. In: B. Hayden (ed.) Lithic Use-Wear Analysis, pp. 97111. Academic Press, New York.

Crabtree, Don

1972 Introduction to Flintworking. Occasional Papers of the Idaho State Museum, 28:198.

Feathers, James K., Vance T. Holliday, and David J. Meltzer 2006 Optically Stimulated Luminescence Dating of Southern High Plains Archaeological Sites. Journal of Archaeological Science, 33:1651-1665. 
Ferring, C. Reid

2001 The Archaeology and Paleoecology of the Aubrey Clovis Site (41DN479) Denton County, Texas. Center for Environmental Archaeology, University of North Texas, Denton.

Fredlund, Glenn, Vance T. Holliday, and Eileen Johnson 2003 Vegetation Change on the Southern High Plains during the Pleistocene Holocene Transition. Symposium paper presented at the XVI INQUA Congress, Reno, Nevada.

Friedman, Irving 1983 Paleoclimatic Evidence from Stable Isotopes. In: Stephen C. Porter (ed.), The Late Pleistocene, Late Quaternary Environments of the United States. Vol.1, pp. 385-389. University of Minnesota Press, Minneapolis.

Haragan, Donald R.

1983 Blue Northers to Sea Breezes. Texas Weather and Climate. Hedrick- Long Publishing Co., Dallas.

Hayden, Brian

1981 Subsistence and Ecological Adaptations of Modern Hunter/Gatherers. In: Robert S.O. Harding and Geza Teleki (eds.), Omnivorous Primates: Gathering and Hunting in Human Evolution, pp. 344-421. Columbia University Press, New York.

Hillsman, Matthew J.

1992 Evaluation of Visible and Ultraviolet-Excited Attributes of some Texas and Macroscopically Similar New Mexico Cherts. Unpublished Masters Thesis, Eastern New Mexico University, Portales.

Hofman, Jack L., Lawrence C. Todd, and Michael B. Collins 1991 Identification of Central Texas Edwards Cherts at the Folsom and Lindenmeier Sites. Plains Anthropologist, 36:297-308.

Holliday, Vance T. 1995 Stratigraphy and Paleoenvironments of Late Quaternary Valley Fills on the Southern High Plains. Geological Society of America Memoir, 186:1-136.

1997 Paleoindian Geoarchaeology of the Southern High Plains. University of Texas Press, Austin.

2004 Soils in Archaeological Research. Oxford University Press, Oxford.

Holliday, Vance T., James H. Mayer, and Glen G. Fredlund 2008 Late Quaternary Sedimentology and Geochronology of Small Playas on the Southern High Plains, Texas and New Mexico, U.S.A. Quaternary Research, 70:11-25. 
Humphrey, John D. and C. Reid Ferring

1994 Stable Isotopic Evidence for Latest Pleistocene and Holocene Climatic Change in North-Central Texas. Quaternary Research, 41(2):200-213.

Hurst, Stance and Eileen Johnson

2012 Adair-Steadman (41FS2) - Mapping and Survey at a Folsom Site in the Brazos River Drainage on the Southern Plains. Museum of Texas Tech University, Lubbock Lake Landmark Quaternary Research Center Series, 20:1-72.

2016a. Adair-Steadman (41FS2) - Survey and Test Excavation at a Folsom Site in the Brazos River Drainage on the Southern Plains. Museum of Texas Tech University, Lubbock Lake Landmark Quaternary Research Center Series, 23:1-73.

2016b. Gearing up at the Adair-Steadman (41FS2) Folsom Site. Paleoamerica, 2:252260.

Johnson, Eileen 1986 Late Pleistocene and Early Holocene Vertebrates and Paleoenvironments on the Southern High Plains, U.S.A. Géographie Physique et Quaternarie, 40:249-261.

1987 Lubbock Lake. Late Quaternary Studies on the Southern High Plains. Texas A\&M University Press, College Station.

1991 Late Pleistocene Cultural Occupation on the Southern High Plains.

In: Robson Bonnichsen and Karen L. Turnmire (eds.), Clovis: Origins and Adaptations, pp. 215-236. Center for the Study of the First Americans, Oregon State University, Corvallis.

2002 Holocene Investigations at the Lubbock Lake Landmark. The 1991 Through 2000 Work. Museum of Texas Tech University, Lubbock Lake Landmark Quaternary Research Center Series, 11:1-323.

2007 Grassland Ecosystems of the Llano Estacado. In: Ronald E. Sosebee, David B. Wester, Carlton M. Britton, E. Durant McArthur, and Stanley G. Kitchens (eds.), Shrubland Dynamics: Fire \& Water. U.S. Department of Agriculture, Forest Service, Rocky Mountain Research Station, Fort Collins, Colorado, Proceedings RMRS-P-47:11-23.

2017 The Younger Dryas and Plainview Paleoecology on the Llano Estacado. In: Vance T. Holliday, Eileen Johnson, and Ruthann Knudson (eds), Plainview. The Enigmatic Paleoindian Artifact Style of the Great Plains. University of Utah Press, Salt Lake City, pp. 103-121.

Jones, J. Knox Jr., David M. Armstrong, and Jerry R. Choate 1985 Guide to Mammals of the Plains States. University of Nebraska Press, Lincoln. 
Kaplan, Hillard and Kim Hill

1992 The Evolutionary Ecology of Food Acquisition. In: Eric Alden Smith and Bruce Winterhalder (eds.), Evolutionary Ecology and Human Behavior, pp. 167-201. Aldine De Gruyter, New York.

Lindelius, Ernest L., Jr., Russel W. Graham, Elaine Anderson, John Guilday, J. Allan Holman, David W. Steadman, and S. David Webb

1983 Terrestrial Vertebrate Faunas. In: Stephen C. Porter (ed.), The Late Pleistocene, Late Quaternary Environments of the United States. Vol. 1, pp. 311-353. University of Minnesota Press, Minneapolis.

MacEwen, Corrine L., Eileen Johnson, Thomas J. Martinez, Paul Backhouse, and Briggs Buchanan 2006 Adair-Steadman (41FS2) - Mapping and Survey at a Folsom Site in the Brazos River Drainage on the Southern Plains. The 1999 Through 2004 Work. Museum of Texas Tech University, Lubbock Lake Landmark Quaternary Research Center Series, 13:1-45.

Martin, Samuel Clark 1975 Ecology and Management of Southwestern Semidesert Grass-shrub Ranges. The Status of Our Knowledge. Rocky Mountain Forest and Range Experiment Station, Fort Collins. USDA Forest Service Research Paper RM-156:1-36.

Martin, Samuel Clark and Howard L. Morton 1993 Mesquite Control Increases Density and Reduces Soil Loss in Southern Arizona. Journal of Range Management, 46:170-175.

Parker, Kenneth William and Samuel Clark Martin 1952 The Mesquite Problem on Southern Arizona Ranges. USDA Circulation, 908:1-70.

Nordt, Lee C., Thomas W. Button, Charles T. Hallmark, and Michael R. Waters 1994 Late Quaternary Vegetation and Climatic Changes in Central Texas Based on the Isotopic Composition of Organic Carbon. Quaternary Research, 41:109-120.

Odell, George $\mathrm{H}$. and Frieda Odell-Vereecken 1980 Verifying the Reliability of Lithic Use-Wear Assessments by 'Blind Tests': the Low Power Approach. Journal of Field Archaeology, 71:87-120.

Osborn, Alan J.

2014 Eye of the Needle: Cold Stress, Clothing, and Sewing Technology during the Younger Dryas Cold Event in North America. American Antiquity, 79:45-68.

Parker, Kenneth William and Samuel Clark Martin 1952 The Mesquite Problem on Southern Arizona Ranges. USDA Circulation, 908:1-70. 
Reeves, C.C. Jr.

1973 The Full-Glacial Climate of the Southern High Plains, West Texas. Journal of Geology, 81:693-704.

Rossignol, Jacqueline and Luann Wandsnider

1992 Space, Time, and Archaeological Landscapes. Plenum Press, New York.

Savage, Stephen $\mathrm{H}$.

1990 Modeling the Late Archaic Social Landscape. In: Kathleen M.S. Allen, Stanton W. Green, and Ezra B.W. Subrow (eds.), Interpreting Space: GIS and Archaeology, pp. 330-355. Taylor and Francis, London.

Schmidly, David J.

2004 The Mammals of Texas. 6th edition. University of Texas Press, Austin.

Smith, Eric Alden and Bruce Winterhalder

1992 Natural Selection and Decision-Making: Some Fundamental Principles. In: Eric Alden Smith and Bruce Winterhalder (eds.), Evolutionary Ecology and Human Behavior, pp. 25-60. Aldine De Gruyter, New York.

Shelford, Victor E.

1963 The Ecology of North America. University of Illinois Press, Urbana.

Smith, George I. and F. Alayne Street-Perrott

1983 Pluvial Lakes of the Western United States. In: Stephen C. Porter (ed.), The Late Pleistocene, Late Quaternary Environments of the United States. Vol. 1, pp. 190-212. University of Minnesota Press, Minneapolis.

Sullivan, Alan P. III and Kenneth C. Rozen

1985 Debitage Analysis and Archaeological Interpretation. American Antiquity, 50: 755779.

Tiedemann, Arthur R. and James O. Klemmendson

2004 Responses of Desert Grassland Vegetation to Mesquite Removal and Regrowth. Rangeland Ecology and Management, 57:455-465.

Trevey, Sterling Scott and Matthew McEwen 2012 Heritage Landscape Management at the Lubbock Lake Landmark for the 2006 through 2010 Seasons. In: Eileen Johnson (ed.), Late Quaternary Investigations at the Lubbock Lake Landmark. The 2006 through 2010 Work. Museum of Texas Tech University, Lubbock Lake Landmark Quaternary Research Center Series, 21. 
Winterhalder, Bruce and Eric Alden Smith

1992 Evolutionary Ecology and the Social Science. In: Eric Alden Smith and Bruce Winterhalder (eds.), Evolutionary Ecology and Human Behavior, pp. 3-23. Aldine Gruyter, New York.

Winterhalder, Bruce and Carol Goland 1997 An Evolutionary Ecology Perspective on Diet Choice, Risk, and Plant Domestication. In: Kristen J. Gremmillion (eds.), People, Plants, and Landscapes, pp. 123-160. University of Alabama Press, Tuscaloosa.

Wright, Henry A. and Arthur W. Bailey 1982 Fire Ecology: United States and Southern Canada. John Wiley and Sons, New York City. 